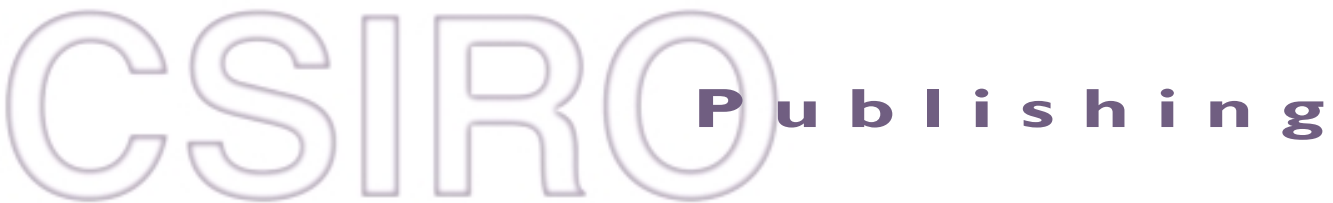

\section{Australian}

Journal of

Agricultural

Research

(c) CSIRO 2001

A journal for the publication of original contributions

towards the understanding of an agricultural system

\section{All enquiries and manuscripts should be directed to:}

Australian Journal of Agricultural Research

CSIRO Publishing

PO Box 1139 (150 Oxford St)

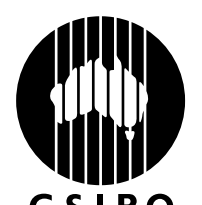

Collingwood, Vic. 3066, Australia

Telephone: +6139662 7628

Fax: +6139662 7611

PUBLISHING Email:ajar@publish.csiro.au

Published by CSIRO Publishing

for CSIRO and the Australian Academy of Science

www.publish.csiro.au/journals/ajar 


\title{
Genetic improvement and agronomy for enhanced wheat competitiveness with weeds*
}

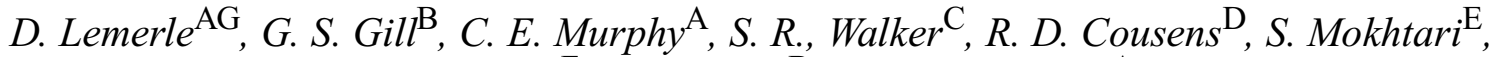 \\ S. J. Peltzer ${ }^{\mathrm{F}}, R$. Coleman ${ }^{\mathrm{B}}$, and D. J. Luckett ${ }^{\mathrm{A}}$ \\ ${ }^{A}$ Wagga Wagga Agricultural Institute, Cooperative Research Centre for Weed Management Systems, \\ NSW Agriculture, PMB, Wagga Wagga, NSW 2650, Australia. \\ ${ }^{\mathrm{B}}$ Department of Agronomy and Farming Systems, Adelaide University, Cooperative Research Centre for \\ Weed Management Systems, Roseworthy, SA 5371, Australia. \\ ${ }^{\mathrm{C}}$ Leslie Research Centre, Farming Systems Institute, Department of Primary Industries, \\ Toowoomba, Qld 4350, Australia. \\ ${ }^{D}$ Institute of Land and Food Resources, The University of Melbourne, Cooperative Research Centre \\ for Weed Management Systems, Vic 3010, Australia. \\ ${ }^{E}$ Faculty of Agriculture, University of Western Australia, Cooperative Research Centre for Weed Management \\ Systems, Nedlands, WA 6907, Australia. \\ ${ }^{F}$ Agriculture Western Australia, Albany, WA 6330, Australia. \\ ${ }^{\mathrm{G}}$ Corresponding author; e-mail: deirdre.lemerle@agric.nsw.gov.au
}

\begin{abstract}
The rapid development of herbicide resistance in weeds, and environmental imperatives, have forced the consideration of non-chemical tactics such as crop competition for weed management. This review of wheat-weed competition examines the plant traits associated with wheat competitiveness, and the opportunities for plant breeding or manipulating crop agronomy to differentially favour the growth of the crop. Many studies have proven that enhancing crop competitive ability can reduce weed seed production and crop yield loss, although a number of difficulties in conducting this research are identified and suggestions are made for improvement. It remains to be seen whether crop competitiveness will be considered as a priority by farmers and plant breeders. Farmers require precise information on the reliability of agronomic factors such as increased crop seeding rate or choice of variety for enhancing crop competitive ability in different environments. Plant breeders need to know which plant traits to incorporate in varieties to increase competitive ability. A thorough analysis of the benefits and costs of enhancing wheat competitiveness is needed. Competitive wheat crops should be available as part of reliable and economical integrated weed management packages for farmers.
\end{abstract}

Additional keywords: herbicide resistance, plant traits, crop morphology, variety, competitive ability, interference, seeding rates, weed suppression, yield loss, crop tolerance, biotechnology.

\section{Introduction}

The availability of selective herbicides for the last 30 years has enabled farmers to successfully grow high-yielding wheat varieties bred to achieve optimal yields in weed-free conditions. However, herbicide resistance, and therefore weed survival in crops, is resulting in reduced grain yields and limited cropping options (Powles et al. 1997). This has led to a need to reconsider the role of crop competition for weed management. Furthermore, evidence suggests that the modern semi-dwarf wheats may be less competitive than the older standard types (e.g. Lemerle et al. 1996a), and this has implications for the future objectives of wheat breeding programs.

The first worldwide report of a weed biotype resistant to one of the early selective herbicides, an ACCase inhibiting herbicide (Group A), was in Lolium rigidum (annual ryegrass) in Australia in 1980 (Heap and Knight 1982). Now about 100 cases of different herbicide-resistant weed species are reported in 20 wheat-producing countries of the world; $75 \%$ are resistant to Group A and Group B (ALS inhibitors) herbicides (Thill and Lemerle 2001). Evidence suggests that in the future this rapid rate of resistance evolution will

*This review is one of a series commissioned by the Advisory Committee of the Journal. 
continue in the intensive wheat-cropping areas of Europe and North America, and expand in developing countries such as China (Thill and Lemerle 2001). In Australia at present, the most significant resistance is in L. rigidum in the southern cropping zone, and this weed has resistance to 6 major herbicide groups (Preston et al. 1999). In the south, another 7 weed species, including Avena spp. and Raphanus raphanistrum, have developed resistance, while in the north, 8 species are confirmed resistant to 3 herbicide groups (Preston et al. 1999).

The widespread development of herbicide resistance results from continuous cropping systems being highly dependent on herbicides, the high population densities of some weed species, and the repeated use of certain herbicide groups. In some situations, farmers no longer have postemergence herbicide options available to them. Resistance has therefore begun to force farmers to undertake integrated weed management, which involves a greater reliance on nonchemical control tactics such as enhancing the competitive ability (CA) of the crops. Reducing farmers' dependence on herbicides is also desirable to reduce herbicide costs and minimise environmental contamination. The reliability of herbicide performance can be improved when combined with crop species or varieties of superior competitiveness (e.g. Christensen 1994; Lemerle et al. 1996b). This is especially important under the variable climatic conditions of dryland cropping systems.

Competition occurs in communities when two or more plants seek a common resource within a limited space, such as mineral nutrients, light, and water. This can be between individuals of the same species (intraspecific) or between individuals of different species (interspecific). The term 'interference' describes an induced effect by an individual on a neighbour through changes in the environment and brought about by the proximity of neighbours, and this includes competition and allelopathy (production of toxins) (Harper 1977). Competition is often used as a synonym for 'interference', as it is in this review. The CA of a crop can be measured either as suppression of weed growth and seed production by the crop, or as crop yield loss, which is the ability of the crop to tolerate weed presence and maintain grain yield, 'crop tolerance' (Goldberg 1990; Jordan 1993). Jordan (1993) argues for the need to separate weed suppression from crop tolerance in a competitive variety, as these may result from different mechanisms. For example, differential varietal responses to weed competition might occur if some varieties have peak resource demands at times when weed resource use is low even if weed density is high (Jordan 1993). Crop tolerance and weed suppression, the two crop CA traits, may not necessarily be present in the same variety, and in most studies only one is usually measured. In wheat, crop tolerance and weed suppression have been shown to be to broadly correlated (e.g. Challaiah et al. 1986; Lemerle et al. 1996a). The ideal variety will have high yield potential in both weedy and weed-free situations. It will tolerate weeds and significantly suppress weed growth. Weed suppression may be considered the most agronomically desirable trait, since it controls weed populations into the future, and therefore has long-term implications for management of weeds. However, this will depend on its effectiveness, and use by farmers in combination with other control tactics. The mechanisms underlying the superior competitiveness of varieties will be discussed in detail later.

Ultimately, growers would like to be provided with a ranking of wheat varieties for $\mathrm{CA}$, as part of the normal varietal characteristics. This would enable the grower to choose strongly competitive varieties, a relatively low-cost management option, where weeds are expected to be a problem. Any penalties associated with $\mathrm{CA}$, such as reduced yield potential or quality, must be identified and communicated to growers.

If breeding for wheat $\mathrm{CA}$ is shown to be desirable, breeders will need to understand the mechanisms controlling weed-crop competition. A large number of questions need to be answered in order to determine the economic feasibility of enhancing the CA of wheat for weed management. What is the variation in the CA of wheat varieties? Which morphological characteristics of wheat are associated with CA? What are the associated costs of increasing crop CA? Is it possible to make wheat more competitive by simply manipulating crop agronomy? What impact do environmental factors have on the weed-crop interaction? The research discussed in this review has identified the existence of large genetic differences in CA of wheat varieties to weeds, indicating the potential to identify current varieties with $\mathrm{CA}$, or to select material in the later stages of a breeding program (Jordan 1993; Lemerle et al. 1996a). If heritable traits that confer CA can be identified, breeding for these traits can occur. Alternatively, simply manipulating the crop agronomy to increase wheat CA may be an attractive low-cost alternative to genetic improvement (Jordan 1993). It is likely that a combination of short-term agronomic manipulations combined with a longer term breeding effort will be the optimal scenario for increasing wheat CA. However, the success of wheat competitiveness as a weed management tool will ultimately depend on the benefits and costs of the tactic.

Most of the recent research in Australia on wheat CA involves spring wheat growing in mixture with L rigidum. This combination serves as a useful case study for examining the potential to increase wheat $\mathrm{CA}$ in general. The widespread distribution and success of $L$. rigidum as a weed of wheat in southern Australia is attributed to high genetic variability and plant densities, prolific seed production, and successful adaptation to varying habitats through an excellent capability to tiller and exploit the available space (Gill 1996a). L. rigidum can cause large yield losses in wheat 
depending on the relative densities of the weed and crop, time of emergence, and resource availability (Gill 1996b).

The wide range in crop CA in different species is outlined briefly in the next section, as a backdrop to the more detailed examination of the benefits of wheat variety CA. We then discuss the crop traits associated with competitive ability, the possibility of breeding strongly competitive varieties or manipulating crop agronomy to favour the crop, and the potential costs associated with these alternatives.

\section{Crop species variation in $\mathrm{CA}$}

Many studies have identified large differences in the CA of different broad-acre crop species. A review by Van Heemst (1985) showed that mean yield loss from weeds ranged from $25 \%$ in wheat to $49 \%$ in transplanted rice to $77 \%$ in sugar beet and $100 \%$ in onions. Pavlychenko and Harrington (1934) first considered CA of broad-acre crop species with Avena fatua in Canada. They ranked barley and cereal rye as more competitive than wheat and flax. Since then, many crop-weed competition studies have been conducted throughout the world to determine the competitiveness of crop species. Nalewaja (1978) in the USA showed that rye was more competitive than barley or wheat. In the UK, cereal rye and oats had superior CA to wheat and grain legumes (Millington et al. 1990), whereas barley was more competitive than oilseed rape or field peas (Lutman et al. 1994). In Denmark, Melander (1993) ranked peas and oilseed rape as less competitive than rye, wheat, or barley. More recently in the UK, Seavers and Wright (1999) found significant differences in the interference of crop species against Galium aparine, oats being the most suppressive, followed by barley and then wheat.

In the Australian wheat-belt, crop yield loss from L. rigidum ranged from less than $10 \%$ in the most competitive species, to $100 \%$ with the weakest; the species ranking for competitiveness from strong to weak was oats, cereal rye, triticale, oilseed rape, barley, wheat, field pea, and lupin (Lemerle et al. 1995). In the northern cropping region, barley was much more competitive than wheat with Avena ludoviciana and Phalaris paradoxa (Walker et al. 1998).

In summary, it seems that of the broad-acre crops, cereals, particularly oats, cereal rye, and barley, are generally more competitive than wheat or oilseed rape, whereas pulses are poorly competitive. The considerable variation that exists in the measured CA of different crop species will be due in part to the variety, weed species, plant densities, and environmental factors examined in each study.

\section{Variation in CA due to wheat variety}

Considerable research has been undertaken on the CA of wheat, due to the economic importance of the crop and the diversity of varieties grown throughout the world. Studies have been reported from many places, including India (Balyan et al. 1991), the UK (Moss 1985; Richards 1989;
Richards and Whytock 1993), Canada (Blackshaw 1994; Huel and Hucl 1996), the USA (Appelby et al. 1976; Challaiah et al. 1983, 1986; Wicks et al. 1986), Mexico (Reynolds et al. 1994), Denmark (Christensen 1994), and Germany (Verschwele and Niemann 1993). For example, one of the largest studies was undertaken by Challaiah et al. (1983), who evaluated the yield of 85 winter wheat varieties grown in the field and glasshouse with and without Bromus tectorum. At similar weed densities, many varieties were identified as having significantly greater yields than the widely grown Centurk 78. Challaiah et al. (1986) also compared the CA of 10 winter wheat varieties and found a range in B. tectorum dry matter production from 1900 to $3249 \mathrm{~kg} / \mathrm{ha}$ when competing against different varieties at one site, compared with 1100-1970 kg/ha at another site. Corresponding yield losses between the varieties ranged from $9-21 \%$ at one site to $20-41 \%$ at the other. In another example, Verschwele and Niemann (1993) found that differences in the CA of 3 wheat varieties over 3 years and 2 sites was the highest in Andrea followed by Catinka and then Ermo. In the UK, Seavers and Wright (1999) found inconsistencies in suppression of $G$. aparine in 2 years, possibly due to a seasonal interaction.

In Australia, differences in CA of wheat against L. rigidum have been reported (Reeves and Brook 1977; Lemerle et al. 1979; Reeves et al. 1993; Lemerle et al. 1996a, 1996b, 2001; Cousens and Mokhtari 1998; Gill and Coleman 1999). Some of these studies compared the ranking of varietal CA against a single density of L. rigidum (usually between 200 and 500 plants $/ \mathrm{m}^{2}$ ) resulting in yield losses from zero to $50 \%$ depending on variety. In general, these studies have shown considerable variation in varietal ranking. Genetic variation in wheat $\mathrm{CA}$ is often confounded with effects of site and season, and therefore ranking of current varieties is inconsistent between environments (Cousens and Mokhtari 1998; Lemerle et al. 2001). Based on these studies, making reliable recommendations for farmers is difficult. However, broad recommendations identifying several strongly competitive varieties for different regions have been made available (GRDC 1998).

The possible negative relationship between wheat CA measured as crop tolerance to weeds and weed-free yield potential is of concern (Donald and Hamblin 1976). In the UK, wheat varieties that produced the greatest grain yield in weed-free plots were the most severely affected by weed competition (De Lucas and Froud-Williams 1994). In contrast, in Australia no relationship was observed between weed-free yield and percentage yield loss (Lemerle et al. 1996a, 2000; Cousens and Mokhtari 1998; Gill and Coleman 1999, 2000). For example, some of these data are shown in Fig. 1, where a slight trend towards an inverse relationship is apparent. Clearly, any association or non-association will depend heavily on the range of genotypes tested and the 


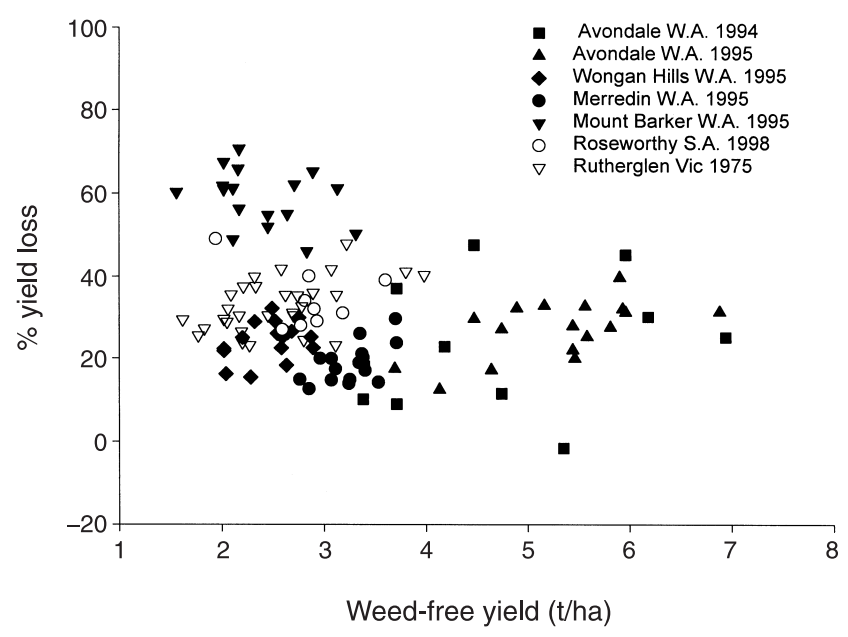

Fig. 1. Association between wheat weed-free grain yield potential (t/ha) and crop tolerance (\% yield loss) to L. rigidum of a wide range of wheat varieties from southern Australia, from Reeves and Brook (1977), Cousens and Mokhtari (1998), and Gill and Coleman (1999).

magnitude of the environmental and genotype $\times$ environment variation.

Crop tolerance to weeds is presented as a percentage yield loss; however, the absolute yield of a variety is also of interest to farmers and breeders. A poorly competitive variety with a high weed-free yield potential may still yield more in the presence of weeds than a low yield potential, strongly competitive variety. Australian data show a strong positive correlation between weed-free grain yield and weedy yield (Cousens and Mokhtari 1998; Gill and Coleman
1999; Lemerle et al. 2001). For example, in Fig. 2, variety 'A' has a high weed-free yield potential of $6 \mathrm{t} / \mathrm{ha}$ but a low crop tolerance to weeds of $50 \%$ yield loss, whereas variety ' $\mathrm{B}$ ' with a low weed-free yield potential of only $3 \mathrm{t} / \mathrm{ha}$ and a higher crop tolerance of $25 \%$ yield loss still yields more in absolute terms than variety ' $A$ '. Varietal differences in wheat tolerance to weeds are smaller and of less significance than variation in weed-free grain yield. This shows that local adaptation is important for varieties to achieve high yield potential irrespective of the presence of weeds. The ideal variety, such as variety ' $\mathrm{C}$ ' in Fig. 2 would possess both high weed-free yield and strong tolerance to weeds. Therefore, the introduction of greater genetic variability from elsewhere through breeding will be required to significantly increase CA in some Australian wheat. In Australia, it appears that the genetic variation for competitiveness in wheat is smaller than environmental variation for absolute yield and may have been lost from the breeding programs at the late generation selection stage. This is probably due to emphasis on other traits such as grain yield, quality, and disease resistance, and the fact that most of the experiments are conducted in only weed-free situations.

In order to determine the extent of spring wheat $\mathrm{CA}$ in germplasm in Australia and other regions of the world, Lemerle et al. (1996a) screened a representative selection of 250 genotypes (135 from Australia and 115 from other regions) for crop tolerance and weed suppression of L. rigidum. Yield reductions ranged from 0 to $100 \%$ between genotypes, while corresponding weed biomass varied from 0 to $500 \mathrm{~g} / \mathrm{m}^{2}$, and these 2 crop CA traits were broadly

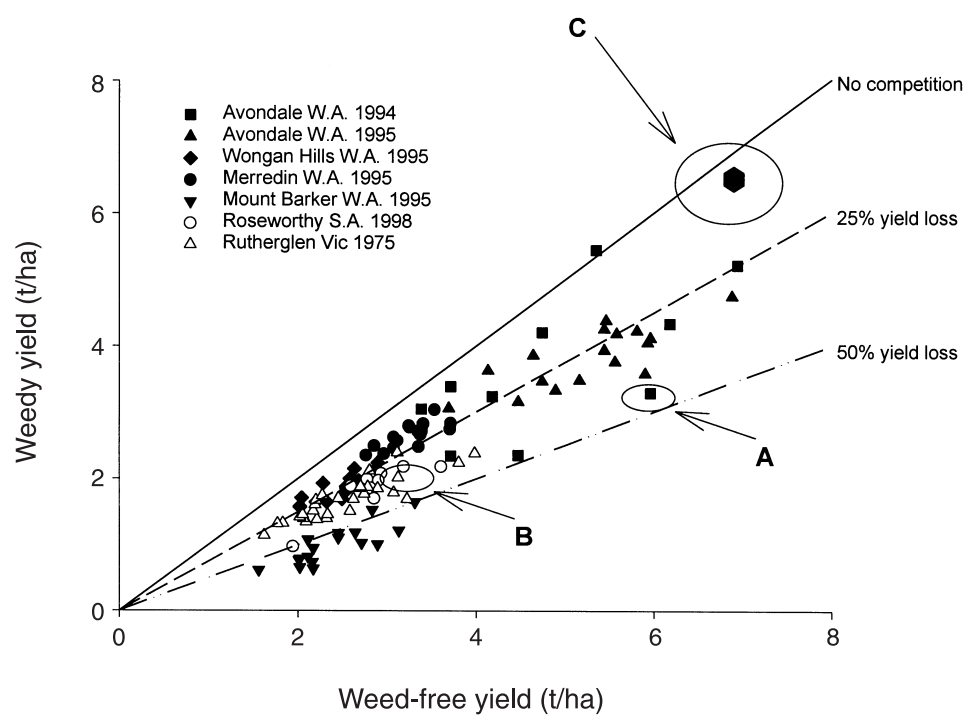

Fig. 2. Association between wheat weed-free grain yield potential $(\mathrm{t} / \mathrm{ha})$ and yield in the presence of $L$. rigidum of a wide range of wheat varieties from southern Australia, from Reeves and Brook (1977), Cousens and Mokhtari (1998), and Gill and Coleman (1999). 'A' is a variety with a high weed-free yield potential and low crop tolerance to weeds, ' $\mathrm{B}$ ' is a variety with a low weed-free yield potential and a higher crop tolerance, ' $\mathrm{C}$ ' represents and ideal variety with a high weed-free yield potential and high crop tolerance. 
Table 1. Suppression of Lolium rigidum grown with wheat genotypes of different origins in Australia and from other regions in the world (from Lemerle et al. 1996a)

Names in parentheses indicate plant breeding organisation

\begin{tabular}{|c|c|c|}
\hline $\begin{array}{l}\text { Source of } \\
\text { genotypes }\end{array}$ & $\begin{array}{l}\text { Number of } \\
\text { values }\end{array}$ & $\begin{array}{l}\text { L. rigidum dry matter } \\
\qquad\left(\mathrm{g} / \mathrm{m}^{2}\right)^{\mathrm{A}}\end{array}$ \\
\hline \multicolumn{3}{|c|}{ Australia } \\
\hline $\mathrm{F}_{1}$ hybrids & 8 & $75(8.7)$ \\
\hline $\begin{array}{l}\text { 'Old' wheats released from } \\
1880-1950\end{array}$ & 11 & $103(10.2)$ \\
\hline Victoria & 24 & $138(11.8)$ \\
\hline New South Wales (Cargill) & 7 & $148(12.2)$ \\
\hline South Australia (Roseworthy) & 14 & $149(12.2)$ \\
\hline $\begin{array}{l}\text { New South Wales (NSW } \\
\text { Agriculture) }\end{array}$ & 15 & $151(12.3)$ \\
\hline $\begin{array}{l}\text { New South Wales (Sydney } \\
\text { University) }\end{array}$ & 14 & $156(12.5)$ \\
\hline South Australia (Waite) & 12 & $169(13.1)$ \\
\hline Queensland & 14 & $173(13.2)$ \\
\hline Western Australia & 9 & $206(14.3)$ \\
\hline $\begin{array}{l}\text { Durum wheats (various } \\
\text { programs) }\end{array}$ & 7 & $259(16.1)$ \\
\hline Mean s.e.d. & & $(0.9)$ \\
\hline \multicolumn{3}{|c|}{ Other regions } \\
\hline South America & 15 & $66(8.2)$ \\
\hline Eastern Europe & 20 & $99(10.0)$ \\
\hline Mexico & 15 & $118(10.9)$ \\
\hline Africa & 13 & $120(10.9)$ \\
\hline Mediterranean & 30 & $125(11.2)$ \\
\hline Middle East & 11 & $161(12.7)$ \\
\hline India & 9 & $187(13.6)$ \\
\hline Mean s.e.d. & & $(1.2)$ \\
\hline
\end{tabular}

${ }^{A}$ Values in parentheses are square-root transformed.

correlated. Significant differences were identified in genotype CA based on origin (Table 1). For example, genotypes from South America and Eastern Europe were more competitive than lines from India, the Middle-East, or Australia. It is possible that genotypes from South America have a high level of acid soil tolerance (Da Silva 1976), which enhances their performance in the moderately acid soils where the experiments were conducted. Australian varieties from Queensland, Western Australia, and northern New South Wales were slightly less competitive than local New South Wales varieties or those bred in the similar environments of Victoria or South Australia. Reeves et al. (1993) also found that locally bred south Australian varieties were more competitive than those bred in other locations. This further indicates the importance of the genotype $\times$ environment interaction on wheat and local adaptation to optimise wheat CA. Results from this study also indicate that the greater competitiveness of genotypes from overseas regions offers the potential to produce improved Australian varieties. The superior competitiveness of the Australian $\mathrm{F}_{1}$ hybrids (Table 1) needs to be examined in more detail. Likewise, the poor CA of durum wheat in southern New
South Wales needs to be understood, and indicates that this species should not be grown in that region when weeds are expected to be a problem.

In summary, differences in wheat CA exist in current varieties, but ranking for $\mathrm{CA}$ is often confounded with environmental factors, making recommendations for farmers unreliable. To achieve greater wheat CA, genetic improvements will depend on an understanding of the plant traits conferring wheat, and the importation of exotic germplasm.

\section{Improved methodology for assessing wheat CA}

One difficulty in studying crop CA with weeds is achieving uniform plant densities (Cousens and Mokhtari 1998; Gill and Coleman 1999). Crop establishment has been used as a covariate to remove the confounding crop density effects (Cousens and Mokhtari 1998). Therefore, it is desirable to measure crop density in these experiments. Choice of weed density may also be important. Reeves and Brooke (1977) used 3 densities of L. rigidum (100, 1000, and 1500 plants/ $\mathrm{m}^{2}$ ) with spring wheat varieties and observed similar trends in wheat CA at each of these densities, although there was less variability in the data at the highest density. In a similar experiment later, Reeves et al. (1993) used 5 lower densities (52-496 plants $/ \mathrm{m}^{2}$ ) and presented the data for only the highest density. It is essential that the weed density used in wheat CA experiments is high enough to ensure an impact on crop growth, but not too high to result in intra-specific competition in the weed. Cousens and Fletcher (1990) suggested the need for a weed density sufficient to give a mean yield reduction of around 50\%. In our experience, densities of at least 400-500 L. rigidum plants $/ \mathrm{m}^{2}$ are often required to separate yield differential between varieties of wheat. However, it would be expected that the optimal weed density would depend on the particular crop-weed association and the relative CA of both species. Although Cousens and Fletcher (1990) provided some evidence from a pot experiment that varietal ranking for competitiveness remains constant across a range of weed densities, further field research is needed to determine whether density can influence variety ranking for wheat CA with weeds.

Caution is needed when considering the range of CA across varieties within an experiment. Competition experiments have greater residual variance than singlespecies experiments of similar size (Cousens 1991), especially where data are expressed as percentage yield loss. Random error will mean that, by chance, some estimates at each extreme may be greater or less than the true mean. As a result, the range will decrease as the number of replicates increases. For example, in Mokhtari's (1998) study, the range of wheat CAs decreased considerably when increasing from 3 to 6 replicates. Detection of the often small varietal differences in CA described in some studies is difficult because of the considerable inherent variability in 
experiments examining variety $\times$ environment $\times$ weed interactions. Provision of additional replication may improve the precision of experiments. The size of plots and interplot gaps may need to be increased to reduce plot-to-plot neighbour effects. The aim is to use an efficient experimental design, which is robust against spatial and other expected effects, and then use the most appropriate method of analysis. Well-designed experiments should have weed-free and weedy plots in close spatial proximity and be analysed using a spatial or split-plot design (B. R. Cullis, pers. comm.).

A strong association between yield reduction in wheat and $L$. rigidum biomass at anthesis or maturity was reported in 2 studies in southern Australia (Lemerle et al. 1996a; Gill and Coleman 1999). Weed suppression may be a more consistent measure of crop CA than crop tolerance (Lemerle et al. 1996a) when examining 2 grass species with similar patterns of growth, such as wheat and L. rigidum. This may be due to greater plasticity of weeds compared with crops. Ideally both CA traits should be measured. Measurement of weed biomass or seed production is particularly important for assisting in the prediction of weed population dynamics. Further study is needed to determine if the association between weed suppression and crop tolerance applies for other weed-crop interactions.

The range of crop CA is influenced by the number of genotypes and the morphological diversity of material tested. Therefore, there is considerable variation in the literature about which traits have the greatest influence on crop CA. When dealing with only a small number of varieties, there is a real danger that traits seen to be present in competitive varieties may be merely chance associations. Moreover, the greater the number of traits examined, the more likely that some of the associations will be spurious and just a result of random variation. Plant traits are rarely independent and generally interact with one another.

The relative contribution of crop traits to wheat CA could also be influenced by the weed species present. This is not surprising because genetic differences in plant morphology and physiology are expected to lead to differential CA in diverse environments. In crop CA experiments, it is therefore important that the experiments are located on uniform sites and representative of the environments where the varieties are normally grown. The influence of agronomic factors such as sowing rate or depth on varietal ranking for CA should be determined. In addition, it is essential to include locally adapted controls of both strongly and weakly competitive varieties. These varieties also need to be included in physiological and modelling studies to get a better understanding of wheat CA.

Experiments examining variety $\mathrm{CA}$ must be conducted at the regional level over a number of seasons, and aim to minimise variation. The most appropriate experimental techniques will depend on the level and spatial distribution of the variability. Measurements of both weed suppression and crop tolerance are required.

\section{Computer simulation modelling}

Computer simulation models have been useful tools in the development of crop ideotypes for high yields in the absence of weeds (Penning de Vries 1991). They can also help identify particular traits of varieties that will give the greatest increases in crop competitiveness with weeds, at least in theory. Moreover, they allow us to separate out interactions between traits that may be confounded within varieties. For example, Lotz et al. (1991) predicted from their model that sugar beet CA with weeds would be enhanced by more rapid rate of early ground cover; this was supported by experiments with 3 varieties differing in leaf angle. Cousens (1996) found from a model of $L$. rigidum competing with wheat that gains in crop CA were more likely to be achieved by increases in early relative growth rate (RGR) than by increasing height or changing the timing of phenological stages. Within existing varieties there were differences in RGR sufficient to provide a $50 \%$ reduction in crop biomass loss from weed competition. Bastiaans et al. (1997) used a growth simulation model to explain differences in CA among rice varieties. They concluded that CA differences between varieties were due to high early RGR and greater height at maturity. However, their model was not entirely able to explain the negative correlation between $\mathrm{CA}$ and yield potential. They also pointed out that the use of models in breeding programs requires continuous interaction between modelling and experimentation.

Current competition models mostly simulate competition for light; sub-models for other resources are, in contrast, either crude or non-existent. It is almost inevitable, therefore, that they will predict a correlation between early growth rate, height, and crop CA. However, under conditions where water and nutrients are severely limiting these models may not give reliable predictions. For example, it is believed that there is considerable competition for nutrients and water between L. rigidum and wheat in the Australian wheat-belt. More realistic models are thus required if we are to use them to explain differences in variety ranking for $\mathrm{CA}$ and contribution of different crop traits to CA under different environments.

Another problem with current models is that they include few parameters that breeders could select for directly, such as tiller number, leaf length, leaf width, and leaf angle. The effects of such individual morphological traits are subsumed in models within gross characters, such as RGR and canopy light extinction coefficient. In addition, many of the models' traits need to be measured destructively, making selection at the individual plant level difficult. Models undoubtedly have a place in work on weed-crop variety competition research, but we need more appropriate models than are currently available. 
Table 2. Characteristics of the cereal ideotype for high grain production in each of three contrasting ecosystems (from Donald and Hamblin 1976)

\begin{tabular}{|c|c|c|c|}
\hline The ecosystem: & A. The plant in isolation & $\begin{array}{l}\text { B. The plant in a mixed } \\
\text { community }\end{array}$ & $\begin{array}{l}\text { C. The plant in a dense } \\
\text { monculture }\end{array}$ \\
\hline The ideotype: & The isolation ideotype & The competition ideotype & The crop ideotype \\
\hline The cereal community: & Widely spaced plants or rows & $\begin{array}{l}\text { The segregating population or } \\
\text { varietal mixture at crop density }\end{array}$ & The crop \\
\hline Criterion of yield: & Weight of grain per plant & Weight of grain per plant & Weight of grain per hectare \\
\hline Competitive ability & Of no significance & $\begin{array}{l}\text { Strong competitive ability } \\
\text { essential }\end{array}$ & $\begin{array}{l}\text { Weak competitive ability; } \\
\text { minimum mutual interference } \\
\text { among like plants }\end{array}$ \\
\hline $\begin{array}{l}\text { Habit and harvest } \\
\text { index }\end{array}$ & $\begin{array}{l}\text { Lax or prostate habit, } \\
\text { permitting leaf cover over } \\
\text { a maximum area }\end{array}$ & $\begin{array}{l}\text { Taller than neighbours, } \\
\text { especially during early } \\
\text { growth and low harvest index }\end{array}$ & $\begin{array}{l}\text { Erect for minimum } \\
\text { interference; dwarfness for } \\
\text { mechanical strength and } \\
\text { high harvest index }\end{array}$ \\
\hline Canopy & $\begin{array}{l}\text { Extensive lead display for } \\
\text { maximum light } \\
\text { interception }\end{array}$ & $\begin{array}{l}\text { Extensive lead display to } \\
\text { shade neighbours, especially } \\
\text { during early growth }\end{array}$ & $\begin{array}{l}\text { Minimum lead display } \\
\text { sufficient only to form an } \\
\text { adequate ear. Minimum } \\
\text { interference with foliage } \\
\text { of like neighbours }\end{array}$ \\
\hline Leaves & $\begin{array}{l}\text { Many long, wide thin, } \\
\text { horizontally disposed } \\
\text { leaves }\end{array}$ & $\begin{array}{l}\text { Many long, wide thin, } \\
\text { horizontally disposed } \\
\text { leaves }\end{array}$ & $\begin{array}{l}\text { Few small, erect leaves to give } \\
\text { favourable light profile and a } \\
\text { higher harvest index }\end{array}$ \\
\hline Root system & $\begin{array}{l}\text { Rapid and sustained growth } \\
\text { of roots to permit water and } \\
\text { nutrient uptake adequate } \\
\text { for maximum growth }\end{array}$ & $\begin{array}{l}\text { Early rapid growth of roots, } \\
\text { exceeding that of neighbours, } \\
\text { particularly into soil } \\
\text { layers likely to be critical } \\
\text { in competition for nutrient } \\
\text { or water }\end{array}$ & $\begin{array}{l}\text { Adequate to ensure sufficient } \\
\text { exploitation of the soil } \\
\text { environment by the whole } \\
\text { community of roots by the } \\
\text { end of the season }\end{array}$ \\
\hline Tillering & Free-tillering & Free-tillering & Sparse or nil tillering \\
\hline Culm survival & High survival & $\begin{array}{l}\text { Enough to exploit the residual } \\
\text { environment, once } \\
\text { dominance has attained }\end{array}$ & Full survival \\
\hline Ear size & Lage ears & Large ears & $\begin{array}{l}\text { Ear size, grains per ear, grain } \\
\text { size not individually critical. } \\
\text { Many flowers per unit of bio- } \\
\text { mass and per unit area. High } \\
\text { weight of grain per unit } \\
\text { of biomass (high harvest }\end{array}$ \\
\hline Grain number per ear & Many grain per ear & Many grains per ear & index) and per unit area when at \\
\hline Grain size & Large grains & Large gains & optimum density \\
\hline
\end{tabular}

\section{Association between plant traits and crop CA}

In order to breed for strongly competitive wheat varieties, an understanding of the mechanisms influencing genetic variation in wheat CA will be beneficial. The morphological, physiological, and biochemical traits of a strongly competitive crop will enable it to capture resources from a weed, or utilise resources more efficiently, than a poorly competitive crop. This association will also be influenced by resource availability, the characteristics of the weed, and other environmental conditions. The timing of the onset of competition will also be influenced by these factors. There has been considerable conjecture about the relationship between crop CA and associated plant traits. Donald and
Hamblin (1976) hypothesised that a 'competition ideotype', which is taller than its neighbours, tillers more, and with an extensive leaf display, will yield well in a mixed community and poorly in monoculture. In contrast, a weakly competitive 'crop ideotype' (short, low tillering, erect leaf display, and high harvest index) would optimise grain yield in monoculture (Table 2, and Fig. 3). A large number of researchers have examined the different morphological traits of wheat varieties and their competitiveness with weeds. De Lucas and Froud-Williams (1994) used the split-box technique to separate above- and below-ground competition between varieties. They compared $4 \mathrm{UK}$ wheat varieties, Maris Huntsman, Maris Widgeon, Riband, and Fresco, and found that differences in CA between varieties were greater 


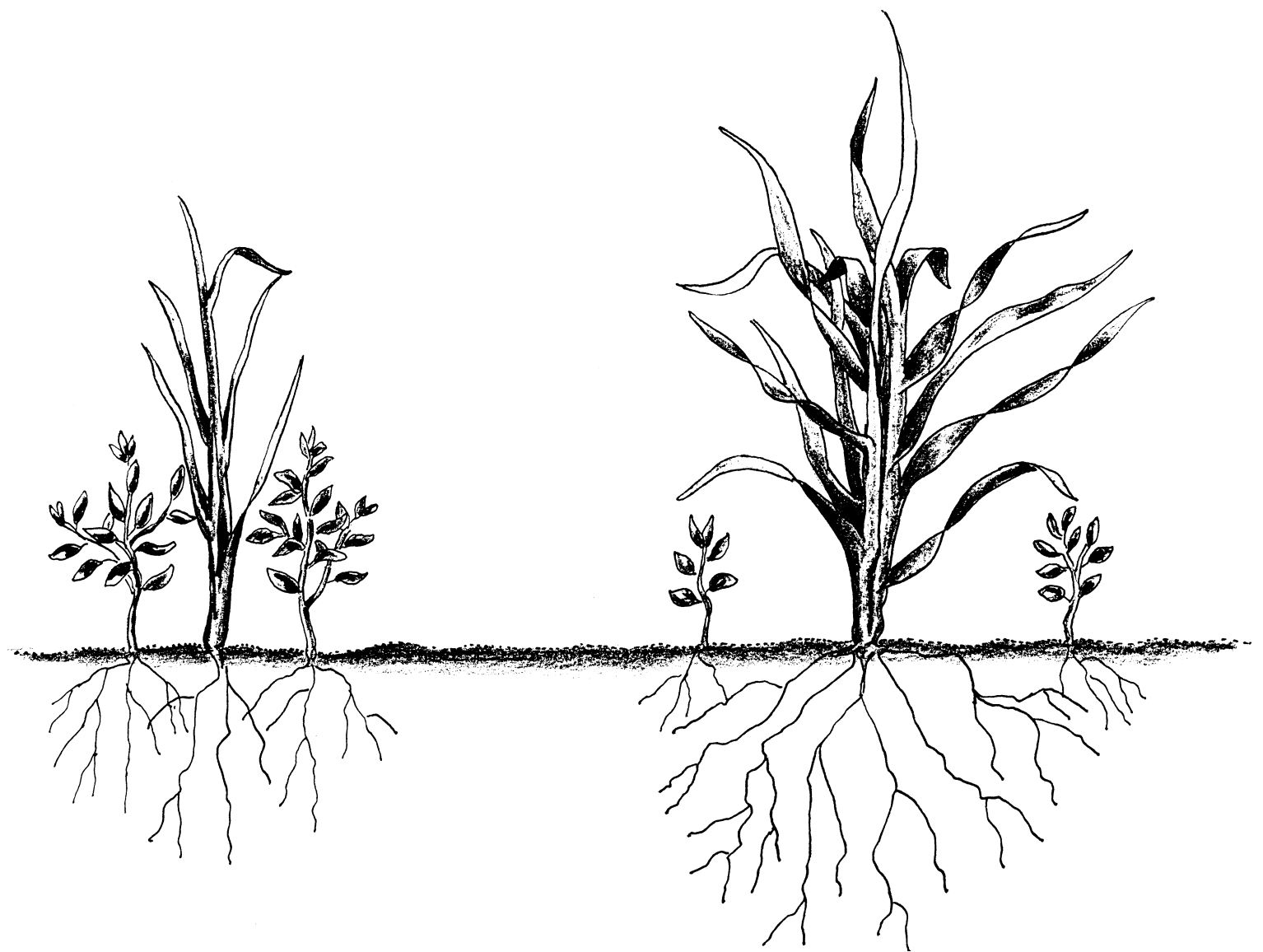

Fig. 3. Illustration of a poorly competitive variety (left) compared with a strongly competitive wheat variety (right) suppressing weeds.

as a result of above- rather than below-ground competition. However, pots and small boxes, due to different light and nutrient environments, may not reflect what will happen in a dense plant stand in the field, so results from these should be treated with caution.

In many environments, the outcome of crop-weed competition is determined early in the season. For example, L. rigidum can reduce wheat growth within 3-6 weeks of emergence (Smith and Levick 1974; Reeves 1976). The most comprehensive studies of the competitive abilities of weeds and cereals were by Pavlychenko and Harrington (1934, 1935). They concluded that the important characters associated with competitive efficiency were development of assimilation surface, stomatal number, readiness and uniformity of seed germination, and distribution and penetration of root systems. Observations over a number of years at Saskatoon examining wheat and barley and a number of grass and broadleaf crops indicated that competition between overlapping root systems takes place long before the tops begin to shade each other (Pavlychenko and Harrington 1935).

Due to the relative ease of measurement, the majority of research has concentrated on above-ground plant traits (e.g. height, tillering, leaf characteristics), which promote light interception, with fewer reports on below-ground crop CA traits (e.g. root growth, allelopathy).

\section{Plant traits promoting light interception and above-ground} crop $C A$

The outcome of weed-crop competition for light is often influenced by the relative heights of competing species. A tall wheat variety is likely to be a better competitor against weeds than a short (semi-dwarf) type due to greater shading ability. Many studies have positively correlated wheat height with crop CA (Hoen and Oram 1967; Appleby et al. 1976; Sturko and Stobbe 1976; Blackshaw et al. 1981; Moss 1985; Wicks et al. 1986; Balyan et al. 1991; Valenti and Wicks 1992; Verschwele and Niemann 1993; Blackshaw 1994; Cosser et al. 1995; Huel and Hucl 1996; Lemerle et al. 1996a; Cosser et al. 1997; Ogg and Seefeldt 1999). In contrast, Reeves and Brooke (1977) found no significant effect of height on varietal tolerance of weeds, although there was a strong tendency for short varieties to be poorer competitors than tall ones. Expression of an association between wheat height and variety $\mathrm{CA}$ is likely to be influenced by the weed type and density, and the 
environmental conditions. For example, Cosser et al. (1997) showed that when seasons or sowing dates led to low weed pressure, the short wheat varieties Herward or Genesis tended to yield more than the older and taller variety Maris Widgeon. Using path analysis, Ogg and Seefeldt (1999) found that early height in winter wheat influenced its CA against Aegilops cylindrica, and this trait was particularly important in dry seasons.

Seefeldt et al. (1999) used near-isogenic lines for wheat height (Rht genes) to examine the relationship between height and competitiveness. The shortest isoline showed the least interference and allowed the greatest amount of A. cylindrica seed production and also showed greatest crop tolerance, but did not have the lowest wheat yield in the presence of the weed. They found that although weed seed production decreased in a linear way with incremental increases in wheat height, the relationship between crop tolerance and height was not linear. Although called 'height' genes; Rht genes have pleiotropic effects on other characters, such as establishment (via coleoptile length). Hence, although strongly suggestive of the influence of height, comparisons of $R h t$ isolines can be equivocal (Flintham et al. 1997)

Breeding in modern varieties has reduced mature plant height and tillering and increased harvest index (see Table 2); thus, it is difficult to separate out the effects of these traits when comparing old with new varieties. At present, mature height is limited in its usefulness in breeding for crop CA because taller plants are often associated with lower yields due to reduction in harvest index and increased susceptibility to lodging. A number of studies identified grain yield cost associated with increased wheat height (e.g. Challaiah et al. 1986; Seefeldt et al. 1999). Fischer and Quail (1990) demonstrated the high yield potential of the double dwarf wheats under optimal conditions. The possible negative association between weed-free yield and crop tolerance or yield loss of wheat, as discussed earlier, appears not to hold for Australian spring wheat with L. rigidum. It is likely that as both weed-free yield potential and crop tolerance of weeds are responses to complex genotypic and environmental variations, the expression is very variable. However, if two current varieties have similar yield potential but differ in height, the taller types could be recommended to farmers for their weedy fields.

Australian and other CIMMYT-derived semi-dwarf wheats containing either $R h t 1$ or $R h t 2$ height-reducing genes produce varieties with shorter and narrower leaves and hence reduced leaf area due to gibberellin-insensitivity (Rebetzke and Richards 1999). However, other height-reducing alleles are available (e.g. $R h t 7, R h t 8, R h t 9, R h t 13$, and $R h t 14$ ) that are known to shorten plant height without making cells insensitive to endogenous gibberellin. These genes are showing promise for improving wheat establishment through the development of longer coleoptiles while maintaining high harvest index and other characteristics associated with Rht1 and Rht2 (Rebetzke et al. 1999).

Many studies suggest that the importance of varietal height or tillering to crop CA may also be linked to other factors such as early crop vigour, leaf characteristics, or shading ability (Appleby et al. 1976; Moss 1985; Challaiah et al. 1986; Wicks et al. 1986; Forcella 1987; Richards 1989; Balyan et al. 1991; Verschwele 1994; Huel and Hucl 1996; Lemerle et al. 1996a; Ogg and Seefeldt 1999; Seavers and Wright 1999). Considerable variation exists in these studies in the relative contribution of particular traits to variety CA. Large differences in the early shading ability of different wheat varieties are shown in Fig. 4. The likelihood of an individual trait being important depends on the amount of variation present, not just importance of the trait for crop CA per se. For example, studies that include varieties with and without major height genes are more likely to conclude that height is important than those only comparing within semidwarf lines. This is not surprising given the complexity of weed-crop interactions, and probably explains why there is much variation in the literature about the relative importance of different traits on crop CA. The relative importance of wheat traits is likely to vary when wheat competes with different weed species. Path analysis provides a useful tool in this type of experimentation (Jordan 1993; Ogg and Seefeldt 1999).

Early vigour is the expression of high relative growth rate, high rate of emergence, or large initial size (often correlated with seed size). An ability to achieve a large size early on will be expected to confer later crop CA, both above and below ground. A crop species with a rapid rate of early growth is likely to have a competitive advantage over its weed neighbours (Lemerle et al. 1979; Cousens 1996; Lemerle et al. 1996a; Bastiaans et al. 1997; Seavers and Wright 1999). However, Cousens and Mokhtari (1998) in Western Australia found no significant relationship between crop yield loss from L. rigidum and early crop plant mass in a low rainfall environment. Crop vigour is usually measured as the plant size or biomass at a particular date. The presence of a coleoptile tiller has been found to contribute significantly to the total plant leaf area and subsequently to early vigour (Liang and Richards 1994), with leaf expansion rate being $25-35 \%$ greater in plants with a coleoptile tiller. R. A. Richards and Z. Lukacs (unpublished data) showed a positive association between early vigour and leaf size, but no association between early vigour and tiller number. Rebetzke and Richards (1996) also identified a strong positive association between coleoptile tiller leaf size and total wheat plant leaf area, and a positive correlation between leaf area and plant biomass 30 days after sowing. An 'aggressivity' coefficient (difference between relative shoot yields of wheat and the weed) was used by Rezaul Karim et al. (1997) to compare the CA of spring wheat varieties against Chenopodium album. High wheat leaf area index and 

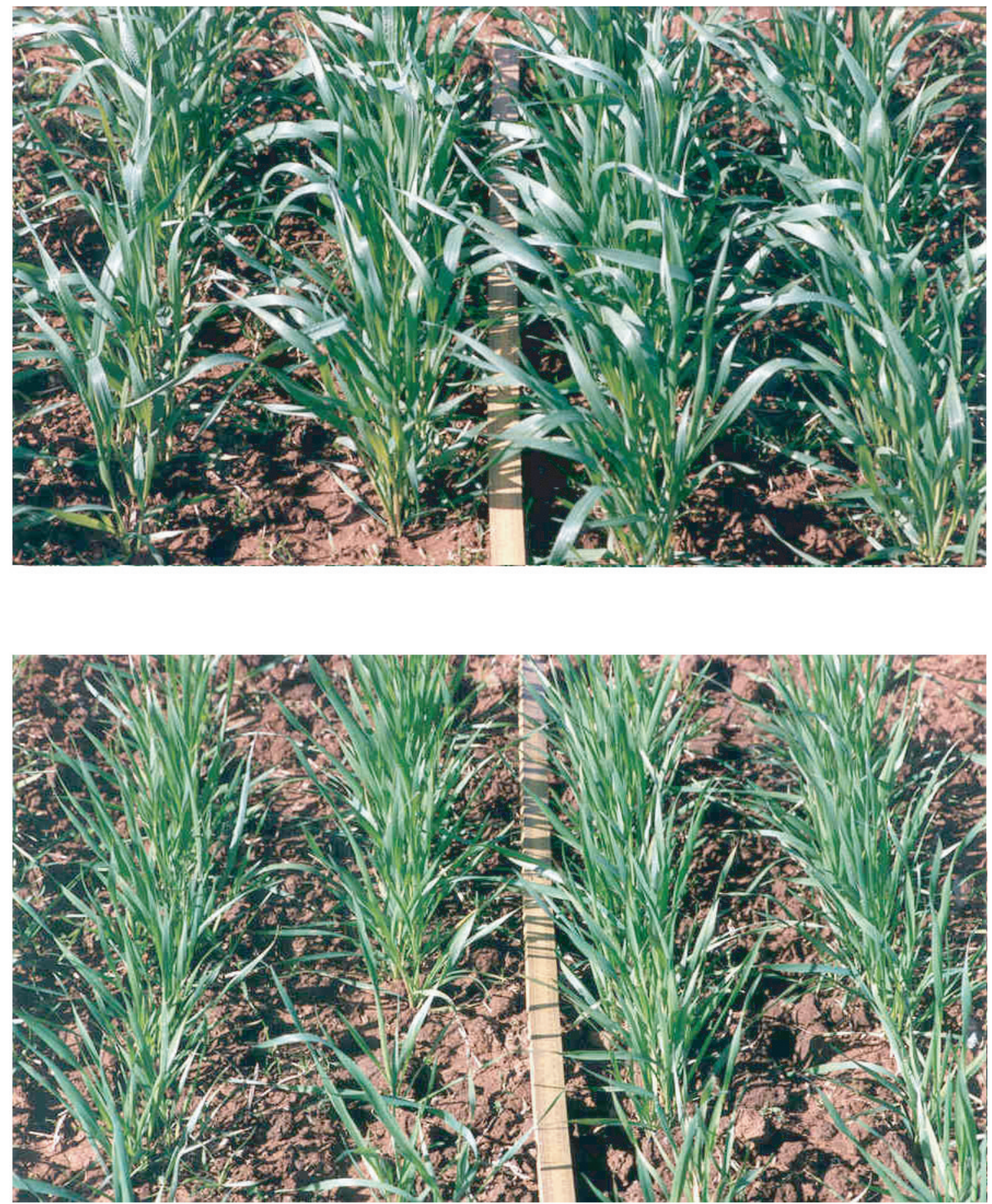

Fig. 4. A strongly competitive wheat variety with extensive leaf display and ground cover (above) compared with a poorly competitive variety (below). Both varieties are at the mid-tillering stage of growth

the ability to maintain grain yield in the presence of weeds were associated with the aggressivity coefficient.

López-Castañeda et al. (1996) compared the early vigour of a number of crop species and found that the size of the embryo contributed to $90 \%$ of the variation, while the remainder was due to earlier emergence. Mokhtari (1998) also showed that early vigour was correlated with seed size in wheat. Barley and triticale exhibited higher early vigour that was associated with the size of the first leaf (LópezCastañeda et al. 1996). Barley also had a greater root length, possibly due to a larger number of seminal roots. They found little useful genetic variation in early vigour among wheat 
varieties currently grown in Australia. However, a large screening of international wheat collections has revealed several overseas varieties with potential to increase early leaf area development in Australian varieties (R. A. Richards, unpubl. data). López-Castañeda et al. (1996) found that the width of the first or second seedling leaf was strongly correlated with early vigour and could be used as an effective selection criterion for early vigour. Rebetzke and Richards $(1996,1999)$ also suggested that leaf width may be utilised to select for varieties with rapid leaf development and early vigour. Selection for early vigour and large leaf size shows promise for breeding for CA, although any penalties associated with this need to be identified.

\section{Plant traits promoting below ground CA}

Despite the undoubted importance of root growth in cropweed competition, only a few studies have been reported (e.g. Pavlychenko and Harrington 1934, 1935; Dotray and Young 1993). Pavlychenko and Harrington (1934) suggested that strongly competitive species, such as Avena fatua, possess a root system with a large mass of fibre close to the soil surface, as well as main roots penetrating deeply. In contrast, the less competitive Marquis wheat had the major part of the root mass at a considerable distance from the soil surface, allowing weeds to become established, because of the scarcity of roots in the upper levels of the soil. They therefore concluded that root distribution has a greater impact on species CA than the size of the root system. Bingham (1995) compared the root growth of A. fatua and spring wheat plants grown in solution culture for 4 weeks after germination, and found that the features of wheat that may contribute to its $\mathrm{CA}$ included a greater number of seminal roots and a high specific root length (root length per unit weight). The initial number of seminal axes can affect the rate of root growth and can therefore provide an early crop CA, while the adventitious root system is also important for CA, mostly during later stages of development (Bingham 1995). Remison and Snaydon (1978) suggested that the ability of the plant to obtain a mobile nutrient, such as nitrogen, is related to the total root system volume, while the uptake of less mobile nutrients, such as phosphorus, is related to the root length density. The use of fertiliser to differentially favour wheat rather than weed growth will be discussed later.

One of the few competition studies examining crop varietal differences in root growth was in rice (Oryza sativa and $O$. glaberrima), in which varieties with greater root lengths were found to cause larger suppression of weed biomass (Fofana et al. 1995). There are no reports of the differential below-ground growth of wheat varieties with a weed species, due to the extreme technical difficulties associated with studying root systems. There is some evidence that the taller standard wheats have a more extensive root system than the semi-dwarfs and presumably greater opportunity to obtain soil resources (Laing and Fischer 1977). Ortiz-Monasterio et al. (1997) showed genetic gains in grain yields and nitrogen use efficiency in modern semi-dwarf compared with older standard varieties, due to both improved uptake and utilisation efficiencies.

An early advantage in plant size may have a negative impact in environments where water is often limiting at the end of the growing season, as in southern Australia and parts of northern America. Early vigour may cause excessive water use in the pre-anthesis phase, leaving inadequate amounts for crop grain filling. Consequently, under such situations early vigour may have little impact on wheat CA measured as yield loss, although large differences in weed suppression may still occur. If early vigour could be combined with earlier timing of anthesis to enable grain filling under more favourable conditions, then it should be possible to overcome this potential disadvantage of early vigour under rain-fed conditions. Murphy (1998) found that yield reductions in wheat competing with L. rigidum were similar under irrigated and dryland conditions in southern Australia, suggesting that water availability had little influence on the intensity of weed-crop competition. In contrast, Fleming et al. (1988) and Ogg and Seefeldt (1999) found that Aegilops cylindrica was more competitive with winter wheat under dry conditions. Pavlychenko and Harrington (1934) commented that as Marquis wheat has most of its roots at a considerable a depth, this type of root system is well adapted for drought resistance and weed competition at depth. However, when competing with a weed like $A$. fatua, which has roots evenly distributed throughout the soil profile, wheat may tolerate the weed but have poor weed suppression ability.

Early-maturing varieties may be tolerant to competition due to greater water availability during grain-filling and ripening (Mokhtari 1998). For example, in Western Australia the late-maturing varieties Machete and Spear were adversely affected by water stress and had a low crop tolerance to weeds (Mokhtari 1998), while the early-maturing varieties Wilgoyne and Gutha maintained their yield. Presumably the latematuring varieties incurred greater loss because of their greater biomass, which meant that soil water was exhausted sooner than in the early varieties (Woodruff and Tonks 1983). In the Canadian prairies, where the growing season commonly ends in terminal drought, differences among winter wheat varieties in the magnitude of crop tolerance to B. tectorum depended on the varieties' abilities to tolerate stress conditions (Blackshaw 1994). Lemerle et al. (1996a) found that in a dry year, a longer time from sowing to head emergence was associated with decreased suppression of $L$. rigidum growing with 135 Australian wheats, whereas there was no such association observed in 115 world wheats grown at the same time.

It has been suggested that semi-dwarf wheat varieties are often more susceptible to terminal drought than taller 
varieties in Canada (Blackshaw 1994) and Australia (Laing and Fischer 1977; Richards 1992). Presumably this is due to differential rooting patterns, or taller types which may have greater buffering capacity due to availability of more stem assimilates (Borrell et al. 1993). The timing of drought is likely to be important for weed-crop competition. It may be that taller wheats are able to deal with terminal drought better than shorter types. However if drought occurs prior to flowering, shorter wheats may be less affected because of less competition between roots and above-ground parts of these plants for assimilates. Paseban-Islam et al. (1999) showed that double-dwarf spring wheat had greater yield and remobilisation under combined pre- and post-anthesis drought than taller types.

The relative morphology and phenology of wheat and weeds, combined with the timing of resource limitation (water or nutrients), relative drought, or nutrient tolerance of the competing species, will strongly influence crop CA. Research is required to determine the principles underlying the differential competitive advantage of some wheat varieties. However, it must be appreciated that there is strong feed-back between below- and above-ground growth.

Root exudates are a potential means by which competitive wheat varieties can reduce weed growth. Allelopathy is the exudation of phytotoxic, secondary metabolites by plants into the growth environment, leading to the suppression in the growth of other plants. The potential of using allelopathy for weed management is well documented (Rice 1995) and was recently reviewed for wheat by $\mathrm{Wu}$ et al. (1999a). Research has examined the genetic variation in allelopathy in rice (e.g. Olofsdotter and Navarez 1996; Dilday et al. 1998). Hashem and Adkins (1996) found variation in inhibition of Avena fatua and Sisymbrium orientale between 19 accessions of Triticum speltoides, a wild but close relative of wheat. In wheat, Wu et al. (1998) found that residues of different wheat accessions caused variation in the suppression of seedling growth of L. rigidum. In another study where the weed and crop were grown together, they showed significant differences in allelopathic potential in a population of 453 wheat accessions, where L. rigidum root growth was inhibited from $10 \%$ to $91 \%$ (Wu et al. 2000). Baghestani et al. (1999) also detected various levels of root exudates in spring wheat, oats, and barley. Examples of the allelochemicals found were benzoic, ferulic, vanillic, and para-coumaric acids (Baghestani et al. 1999; Wu et al. 1999b). The results indicate that considerable genetic variation already exists in the allelopathic activity of wheat, and that this might be controlled by major genes in some plant breeding populations (Wu et al. 2000). Further studies are required to explore the prospect of breeding for strong allelopathy in wheat.

\section{Summary}

Clearly many plant traits influence wheat competitiveness and no one set of characteristics will give strongly competitive wheat plants in all situations. It appears that potential exists for breeding for enhanced wheat CA through greater early vigour and extensive leaf display. However, a greater understanding of the genetic control of the important plant traits and any associated penalties is needed. Only one study with and without the major height genes (Seefeldt et al. 1999) has determined the influence of height on wheat CA. Further studies on traits (e.g. tiller number, leaf waxiness, leaf width, allelopathy, nutrient uptake) are required using isolines for those traits. If relatively simple biochemical pathways are involved, then a transgenic approach could be highly effective. In addition, further comparative studies are needed to quantify the relative phenological and morphological patterns of root growth, and nutrient and water uptake, of different wheat varieties and important associated weeds, to see if strongly competitive varieties are competitive against all weeds. Because of the inherent variability of wheat variety $\mathrm{CA}$, encouraging local agronomists to observe the crop traits associated with low wheat CA will improve farmers' awareness of differences in wheat competitiveness.

\section{Breeding for CA}

Breeding for crop CA is possible but there are associated difficulties. A strong association between a trait and CA is needed in order to establish well-defined breeding objectives. The trait should have a reasonable level of genetic control, and the incorporation of genes for CA must not impose a significant penalty on other important characters (principally yield). The inconsistencies observed in the associations between traits and CA described above makes the choice of target trait difficult, and selection will be impeded since the effects of various traits are confounded. However, if a particular trait can be identified as sufficiently important, such as early vigour, then breeding can be undertaken.

The most appropriate breeding method for CA depends on whether the trait is qualitative or quantitative in nature (Pester et al. 1999). Some traits associated with crop CA are quantitative and require measurements over years and locations to reliably identify the best genotypes. In addition, several generations of crossing will be needed to pyramid all of the genes of minor effect that control the character. Consequently, recurrent selection would most likely be used (Pester et al. 1999). During the recurrent selection process the challenge for the breeder would be to preserve the other desirable characteristics while improving wheat competitiveness. The rate of progress will depend on the range of crop CA available in local varieties and the degree of difficulty and reliability in measuring the character. 
Rebetzke and Richards (1999) and Rebetzke et. al. (1999) have shown that early vigour and long coleoptiles are quantitative characters with high heritability. As such, they can be readily selected for Australian spring wheat breeding programs, and this is already occurring.

The long coleoptile character can only be exploited in the absence of Rht 1 and $R h t 2$ genes (gibberellic insensitive). A semi-dwarf wheat with long coleoptiles will need to have other Rht (gibberellic sensitive) or cumulative minor genes for height (Rebetzke et al. 1999).

A number of other factors will influence the choice of breeding method, including: the crop species' breeding system, the degree of genotype $\times$ environment interaction for crop CA, the availability of techniques for rapid measurement of $\mathrm{CA}$, and the genetic relationship between $\mathrm{CA}$ and other agronomic characters (Callaway and Forcella 1993).

Mokhtari (1998), in Western Australia, found a relationship between wheat height and competitiveness in the progeny of crosses, and between leaf size and CA (measured as crop tolerance), and suggested that these traits may be useful indicators of CA in breeding. However, further investigation indicated that leaf size only had a medium narrow-sense heritability $\left(\mathrm{h}_{\mathrm{N}}^{2}\right)$, estimated as 0.26 , which is insufficient to give reasonable genetic gain without the use of very large population sizes. Rebetzke and Richards (1999) found similar narrow-sense heritability for leaf area $\left(\mathrm{h}_{\mathrm{N}}{ }^{2}=\right.$ $0.30)$ and plant biomass $\left(\mathrm{h}_{\mathrm{N}}^{2}=0.35\right)$, but higher values for leaf width $\left(\mathrm{h}_{\mathrm{N}}^{2}=0.76\right)$ and leaf length $\left(\mathrm{h}_{\mathrm{N}}{ }^{2}=0.67\right)$. They also found a strong genetic correlation between leaf area and leaf width $\left(r_{g}=0.56\right)$. Therefore, selection for leaf width should produce genetic gain in leaf area similar to selection for leaf area per se. Leaf width can be measured or visually assessed in the field much more easily than leaf area.

Mokhtari (1998) attempted to determine the major components of genetic variation in CA between the strong and the poor competitors within each of two wheat maturity groups. Forty $\mathrm{F}_{2}$-derived $\mathrm{F}_{3}$ families from the early $\times$ early cross (Wilgoyne $\times$ Gutha), and 40 from the late $\times$ late cross (Machete $\times$ Spear), were grown in the field with and without $L$. rigidum, to determine whether crop tolerance to weeds was sufficiently heritable to be modified by selection. There were large differences in percentage yield loss $(-30 \%$ to $+82 \%$ ) among $\mathrm{F}_{2}$-derived $\mathrm{F}_{3}$ lines. The broad-sense heritability estimate for crop tolerance was 0.40 for one of the crosses (Wilgoyne $\times$ Gutha) but only 0.14 in the other. The results clearly indicated that selection for high CA produced desirable transgressive segregants or recombinants in the $\mathrm{F}_{3}$ generation. Of course, significant further work was then required to determine whether the lines with high $\mathrm{CA}$ are agronomically suitable in all other respects.

Lemerle et al. (2000) aimed to enhance CA of wheat by selecting for large leaves while maintaining high yield potential. Two populations of wheat were selected from crosses between high-yielding, poorly competitive, locally adapted varieties (Janz and Sunbri) and strongly competitive, vigorous, large-leafed but poorly adapted varieties (Kharchia and Katunga). The progeny from the crosses Janz $\times$ Kharchia and Sunbri $\times$ Katunga were selected for disease resistance and plant type over 2 generations. More than $700 \mathrm{~F}_{2}$-derived $\mathrm{F}_{5}$ genotypes from the two populations were grown in paired field plots, with and without $L$. rigidum at a weed density of 200 plants $/ \mathrm{m}^{2}$. Grain yield was used as a measure of crop CA and yields with and without weed were treated as separate traits. Genotypes which were high-yielding in the absence of weed were also high-yielding when weed was present $(r=0.59)$. A few of the genotypes were high-yielding as well as highly competitive, and will be further evaluated for grain quality. These results indicate that in these populations segregating for yield potential and competitiveness, selecting for weed-free yield indirectly identified genotypes with high yielding ability in the presence of weeds. Consequently, breeding for CA via a pedigree system may simply involve an accurate identification of highly competitive parents and the making of appropriate crosses. It must be acknowledged that if crop CA is to be clearly identified in non-segregating generations, then evaluation in both weedy and weed-free plots will be required. This will significantly increase the cost of breeding but may well be warranted as non-chemical weed control methods become more necessary.

Genotypic differences in tolerance to intraspecific competition from neighbouring crop plants have been used by plant breeders in bulk-population breeding for many years (Harlan and Martini 1938; Sunesen and Wiebe 1942; Allard 1960; Eberhart et al. 1964; Jensen and Federer 1965). In bulk-population breeding, natural selection is allowed to take place for several generations in genetically diverse populations of self-pollinating crops (Callaway and Forcella 1993). Those genotypes that are favoured by the selection environment are automatically selected by the plant breeder. But genotypes that are successful under this weed-free approach are not necessarily those that perform best as fixed lines in monoculture. Luckett and Edwards (1986) and Luckett and Sharif (1987) showed that weed-free bulk or composite populations can remain remarkably diverse even after many generations of inbreeding, presumably due to frequency-dependent selection. The success of many lines in such populations depends on the overall diversity.

Jennings and Aquino (1967) investigated competition between weed-free lines of rice. They concluded that selection in segregating generations grown at high density would favour competitive types which were not necessarily those that give highest yield in pure stand. The extrapolation from this finding is that the same plant characters would give high crop CA against weeds. If the weed is mimicing the crop, then this assumption was more likely to be true. From a breeding perspective Jennings and Aquino (1967) 
Table 3. A simple scoring system for plant breeders to assess wheat genotype competitiveness based on wheat morphology at early stem elongation

1 , low; 3 , intermediate; 5 , strongly competitive

\begin{tabular}{llll}
\hline $\begin{array}{l}\text { Morphological } \\
\text { trait }\end{array}$ & \multicolumn{3}{c}{$\begin{array}{c}\text { Score } \\
3\end{array}$} \\
\hline $\begin{array}{lll}\text { Height } \\
\text { Tiller angle }\end{array}$ & Short & Medium & Tall \\
Leaf width & Erect & Intermediate & Prostrate \\
Leaf length & Narrow & Normal & Wide \\
Vigour (biomass & Short & Intermediate & Long \\
\multicolumn{1}{c}{ estimate) } & Low & Medium & High \\
& & &
\end{tabular}

suggested that low-density, unbiased selections in early generations would solve the problem of losing genotypes with high yield potential but low competitiveness.

The associated costs in plant fitness of increasing wheat CA are not well understood (Pester et al. 1999), and require further study. If the ability to control weeds by herbicides is completely lost (by resistance or legislation) then crop CA may become an essential rather than a desirable character. In this situation breeders may need to conduct all their selection under weedy conditions. In developing countries where chemical control is often prohibitive, crop CA is already a prerequisite. Since stability of yield from season to season in developing countries is crucial ('you eat what you grow') both weed suppression and crop tolerance must be at a maximum even if this is achieved at the expense of optimal, weed-free yield potential.

\section{Variety characterisation for $C A$}

Characterisation of advanced lines and varieties for traits associated with crop CA has occurred in Europe for several years, and this information could be included in the variety description. For example, in the UK variety testing system, straw length gives some indication of wheat CA (Richards 1989). In The Netherlands authorities provide information for winter wheat on earliness of covering the soil, leafiness, leaf angle, and length of straw (Richards 1989). Recording these characters in other variety trial systems could provide useful information on the likely CA of wheat. Verschwele and Niemann (1993) in Germany recommended that screening for CA should be included in standard variety evaluation, using a score based on height, crop cover, and leaf angle. In the UK, Seavers and Wright (1999) suggested that current varieties be indexed on the basis of characteristics that are known to contribute to crop CA. Given the lack of genetic variation for CA in current wheats in some regions of Australia, such a scoring system would probably be ineffective. However, a similar scoring system (Table 3) has been evaluated at the early jointing stage of wheat in segregating generations and found to correlate well with wheat competitiveness (D. Lemerle and B. Verbeek unpublished data). The advantages of such scoring systems are ease of implementation and low cost.

\section{Future directions}

The practical application of transgenic technology to breeding for crop CA appears to be well into the future (Pester et al. 1999). The identification of allelopathic chemicals, elucidation of their biochemistry and genetic control, and the use of transgenic technology to produce crop plants with high CA is a promising area of research (Wu et al. 1999a).

Recent developments in molecular genetics have made it possible to select individuals based on the presence of genes (or closely linked markers) rather than their phenotype (which can be strongly influenced by the interaction between the genotype and the environment). The use of quantitative trait loci (QTL) is a rapid and effective method to select for unknown genes controlling a character (marker-assisted selection or MAS). However, clearly it is necessary firstly to know which traits determine competitiveness. Gill and Coleman (1999) identified QTLs for plant height, leaf size, and time to anthesis in a mapped doubled haploid population of wheat. The QTL approach, or the use of molecular markers for known major genes contributing to crop CA, would be very useful if the character was difficult to measure or the tests were expensive. The use of QTLs would greatly increase the rate of progress in gene pyramiding by recurrent selection.

A new doubled haploid population has been developed from a cross between two elite CSIRO wheat lines developed by R. A. Richards (pers. comm.). Based on parental characteristics, these lines are expected to have larger embryos and greater early vigour than current Australian varieties. The doubled haploid lines will be investigated for their potential as a source of genes for weed competitiveness and for the identification of useful QTLs for various vigour traits, including embryo size.

It remains to be seen whether crop genotypes selected for CA against one weed exhibit the same CA against another. A good example here would be a wheat variety competitive against both $L$. rigidum and $R$. raphanistrum. The emergence patterns and phenological variation between the weed species may make this task difficult.

We may now be in position to replace the static 'competitive ideotype' of Donald and Hamblin (1976) with a temporal or dynamic one, where early CA against weeds is combined with maximum yield potential in the mature crop. If the early interference from the crop is effective, then any weeds present should be small and largely out-competed. Consequently, there may be scope for a relaxation in CA later in the life of the crop plant. So, for example, it may be sufficient for a competitive wheat variety to have early vigour, rapid early root growth, long coleoptiles, and large, floppy leaves but only for the first few leaves. The plant 
could then afford for subsequent leaves to be smaller, with no need for a tall mature height. In this way harvest index could be maintained. If the crop plant's investment in early-stage CA was not too great, then yield penalties in the absence of weeds should not be too high.

In summary, genetic improvement for competitiveness via crop breeding will occur with greater frequency as nonchemical weed control becomes more urgent. Progress will be made by conventional breeding but MAS will greatly speed up this process. Allelopathy seems the most likely area where transgenic technology will have an impact.

\section{Agronomic interactions}

The success of weeds depends on their adaptation to the chemical and cultural practices associated with crop production. The more closely a weed resembles or mimics a crop in habit, ecological requirement, and phenology, the more difficult it is to control without damaging the crop itself (Barrett 1983). For example, the growth of L. rigidum is similar to spring wheat in Australia (Cousens 1996), likewise in north America A. cylindrica and winter wheat are very similar (Fleming et al. 1988). By changing the environment that the weed is adapted to, the opportunities for the weed to succeed will be diminished. A number of agronomic factors, other than choice of variety, are available for enhancing wheat CA against weeds, including seeding rate, spatial arrangement, and fertiliser strategy. It is important to understand the ecological principles associated with enhanced crop CA through agronomic practice for this tactic to be effective for weed management. Choice of crop seeding rate or spatial arrangement will aim to minimise intraspecific competition of the crop and maximise crop capture of resources. Choice of fertiliser strategy will aim to preferentially favour uptake by the crop rather than by the weed. Sowing the crop at its optimal planting time and using good quality large seed will also favour vigorous crop growth. The effectiveness of manipulating wheat agronomy for enhanced crop CA will be influenced by the particular weed-crop association, the soil and climate, and the farming system.

\section{Seeding rate}

The relative benefits of varying rates of seeding for optimal wheat yields under different conditions has been appreciated for a long time. Downing (1921) recommended 'thick' seeding (up to $80 \mathrm{~kg} / \mathrm{ha}$ ) with sparsely tillering varieties or late-sown crops to optimise grain yield before the availability of herbicides. Increasing the crop density decreases the resources available to weeds; consequently, the benefits of increasing crop CA via increased density have been widely studied. Weed suppression improved when crop densities were increased from 350 to 800 plants $/ \mathrm{m}^{2}$ against a number of weed species in the UK (Moss 1985; Korres and Froud-Williams 1997), Denmark (Doll et al. 1995), the USA
(Evans et al. 1991; Barton et al. 1992; Hashem et al. 1998), and Canada (Kirkland 1993; Pageau and Tremblay 1995). Similar benefits have been identified in Australia. For example, in the southern regions where current recommendations for wheat sowing rates are $50-75 \mathrm{~kg} / \mathrm{ha}$ (120-150 plants $\left./ \mathrm{m}^{2}\right)$, L. rigidum biomass was substantially decreased and grain yield increased when wheat densities were increased to 200 plants $/ \mathrm{m}^{2}$ (Medd et al. 1985; Lemerle et al. 1996a). When the crop seeding rate of 10 wheat genotypes (representing a range in wheat variety CA) was doubled from 55 to $110 \mathrm{~kg} / \mathrm{ha}\left(130-200 \mathrm{plants} / \mathrm{m}^{2}\right)$, L. rigidum biomass was reduced by $43 \%$, while crop yield loss was only slightly reduced, and the relative ranking of varieties remained unchanged (Lemerle et al. 1996a). Likewise, in the northern grain region, the crop density which gave the highest wheat and barley grain yields and reduced seed production of Avena spp. and Phalaris paradoxa was approximately 100-150 plants $/ \mathrm{m}^{2}$ (Radford et al. 1980; Martin et al. 1987; Walker et al. 1998). In Western Australia, D. Minkey (unpublished data) and Peltzer (1999), found that wheat grain yields were highest at seed rates of up to $200 \mathrm{~kg} / \mathrm{ha}$, and L. rigidum was suppressed. Fee (1997), quoted by Peltzer (1999), found that increasing seeding rates from 50 to $200 \mathrm{~kg} / \mathrm{ha}$ resulted in a 3 -fold reduction in $L$. rigidum seed production.

A problem with higher crop seeding rates is that farmers are concerned about the cost of extra seed at sowing, and reductions in harvested grain quality and seed size at higher sowing densities. Therefore, adoption to date has been variable. Medd et al. (1985) found only a $10-15 \%$ reduction in average grain mass as wheat density increased from 75 to 200 plants $/ \mathrm{m}^{2}$, and Walker et al. (1998) found a maximum of $2 \%$ reduction in seed size with increased wheat density from 50 to 150 plants $/ \mathrm{m}^{2}$. In Western Australia, an increase in wheat density from 90 to 280 plants $/ \mathrm{m}^{2}$ caused a decrease in grain size of only $5 \%$, and the level of screenings and grain protein was unaffected (G. S. Gill, unpublished data reported in Gill and Holmes 1997). D. Minkey (unpublished data) in Western Australia found that grain screenings remained below $2.5 \%$ at a seed rate of $200 \mathrm{~kg} / \mathrm{ha}$ and row spacings of 90 and $180 \mathrm{~mm}$. Peltzer (1999) found that screenings did not increase detectably at higher seeding rates.

In summary, strong evidence supports the benefit of increasing wheat seed rate to $\geq 100 \mathrm{~kg} / \mathrm{ha}$ for weed suppression, and to a lesser extent crop grain yield, for the wheat-L. rigidum association in southern Australia. The cost of increasing wheat seeding rate from 50 to $100 \mathrm{~kg} / \mathrm{ha}$ would be about AU\$20/ha at current prices, and could lead to almost 50\% reduction in weed biomass and remove the need for a post-emergence herbicide application costing $\$ 40 /$ ha (S. J. M. Sutherland, pers. comm.). High crop seeding rates also have important implications for reducing weed densities in future crops. A thorough economic evaluation of the longterm benefits and costs of increasing wheat seed rate for 
weed management is needed. Further experiments are also required to clarify the risks of reduced grain yield quality at high wheat seeding rates before recommendations are made to growers. Research should be undertaken to determine the merits of higher wheat seeding rates with different weeds and environments.

\section{Crop spatial arrangement}

In theory, the optimal rectangular plant pattern at a given crop density for weed suppression is a square pattern (Fischer and Miles 1973). Some studies have examined the potential of changing the spatial arrangement of cereals to enhance crop CA with weeds (Medd et al. 1985; Barton et al. 1992; Pageau and Tremblay 1995; Hashem et al. 1998; Young et al. 1999). In North America, small reductions in row spacing had no effect on barley yield (18-20 to 9-10 cm) (Barton et al. 1992; Pageau and Tremblay 1995), whereas greater reductions in row spacing (46 to $11 \mathrm{~cm}$ ) increased barley yield (Kirkland 1993). In the USA, Heneise and Murray (1980) found that the CA of field pea was greater at 18 than $36 \mathrm{~cm}$ row spacing. Weed counts in Lupinus albus were also lower at 15 than $75 \mathrm{~cm}$ row spacing (Putnam et al. 1992). Young et al. (1999), also in the USA, found that the only effect of planting geometry (paired and constant rows) of winter wheat on A. cylindria was a reduction of weed spikelet production in paired rows.

In Australia, geometrical arrangement of wheat (rectangularities of 1 to 6.4) had no significant effect on L. rigidum competition over a range of crop densities, and made negligible improvements in wheat yields (Medd et al. 1985). In contrast, in north-western USA, Hashem et al. (1998) found greater L. multiflorum suppression and wheat yield improvement when rectangularity increased from 1 to 16. In both studies, row spacing varied from about 8 to 40 $\mathrm{cm}$. From recent studies in Western Australia, there is some evidence that the CA of wheat with $L$. rigidum decreases at row spacings of $36 \mathrm{~cm}$ compared with $18 \mathrm{~cm}$ at seeding rate of $50 \mathrm{~kg} / \mathrm{ha}$, but at $150 \mathrm{~kg} / \mathrm{ha}$ no interaction was observed (Peltzer 1999; D. Minkey, unpublished data).

Crop placement geometry appears to have little impact on wheat competitiveness, although increases in row spacing reduce wheat $\mathrm{CA}$, especially at low seeding rates. This has important implications for stubble retention systems where wider row spacing is required for sowing through stubble. However, there is evidence that decreases in wheat competitiveness at wide row spacings can be compensated by higher seeding rates, especially in lowtillering varieties.

\section{Fertiliser}

Considerable variation exists in the literature on the impact of fertiliser on the balance of competition between weeds and crops, probably due to differences in growth of the competing species, environmental interactions, and type, timing and placement of fertiliser. The onset of competition can occur early (well before canopy closure and competition for light) suggesting the importance of early root competition between the species as mentioned earlier (e.g. Smith and Levick 1974; Reeves 1976). Forcella (1984) added nitrogen to mixtures of wheat and L. rigidum and found that wheat competed effectively (measured as biomass accumulation) for nitrogen supplied before the 3-leaf stage. However, at the 3-4 leaf stage, wheat lost its ability to use mineral nitrogen effectively, while L. rigidum maintained this ability. He concluded that if wheat is not supplied with adequate nitrogen in the early phases of crop growth, the weed may predominate.

Since weeds and wheat compete for nutrients, the application of fertilisers, particularly nitrogen, can affect the competitive balance between crops and weeds (Forcella 1984; Jørnsgård et al. 1996). Studies have shown that the addition of nitrogen sometimes increases the competitiveness of weeds (Lintell-Smith et al. 1992), in some cases decreases it (Grundy and Froud-Williams 1993), or has no effect (Thurston 1959; Barrett and Campbell 1973). Increasing phosphorus levels from 0 to $60 \mathrm{~kg} / \mathrm{ha}$ did not affect the competition between weeds and barley in Canada (Lêgere et al. 1997), whereas increasing $\mathrm{P}$ and $\mathrm{N}$ increased the $\mathrm{CA}$ of wheat with Phalaris aquatica by increasing its height (Gates et al. 1981). The effect of nitrogen on crop-weed competition can also be affected by weed density (Smith and Levick 1974; Carslon and Hill 1986; Richards 1993). Density of broad-leaved weeds increased with increasing nitrogen rate when in competition with wheat and barley (Richards 1993). However, when weed density was reduced with low doses of herbicides, this effect was reversed and competition was minimised at high rates of nitrogen. As Avena spp. density increased, the addition of nitrogen increased its competitveness and reduced wheat yield (Carlson and Hill 1986). As well as these differences between species and density, quantity, timing and placement of nitrogen application can be important in affecting cropweed interactions (Forcella 1984; Anderson 1991; Angonin et al. 1996).

At high nitrogen levels some weeds are more competitive than others, whereas others predominated at low nitrogen levels (Jørnsgård et al. 1996; Iqbal and Wright 1997). Nitrogen fertilisation (40-160 kg/ha) changed the number and type of weed species in competition with winter wheat in UK (Grundy and Froud-Williams 1993), whereas an increase in nitrogen did not affect the competitive relationship between barley and L. rigidum in Spain (Ponce 1998). Chenopodium album was more effective than barley in competing for low levels of nitrogen (Jørnsgård et al. 1996). As nitrogen increased, barley out-competed C. album due to less light penetrating the canopy. L. rigidum competing with spring wheat was suppressed at very high nitrogen levels due to the high leaf area index and shading ability of the crop (C. E. Murphy, unpublished data). 
Di Tomaso (1995) reviewed the approaches available for manipulating crop CA through fertiliser strategies and suggested that fertiliser placement by banding near the crop seedling, as opposed to broadcast, benefited the early growth of the crop. Banding the fertiliser rather than broadcasting allowed wheat greater access to the fertiliser, which gave it a competitive advantage over the shallower root system of B. tectorum (Rasmussen 1995; Kirkland and Beckie 1998). The benefits of fertiliser banding have also been found for other wheat-weed combinations (e.g. Carlson and Hill 1986; Cochran et al. 1990; Young et al. 1999). While banding is likely to be the simplest way of using fertiliser applications for weed suppression, other tactics such as the use of nitrogen-efficient crop varieties (Ortiz-Monasterio et al. 1997), choice of fertiliser type, and timing of fertiliser application may also increase competitiveness of wheat.

\section{Herbicide interaction}

Since wheat competitiveness can be increased by the above methods, there may be opportunity to decrease herbicide rates and still achieve acceptable herbicide performance. Sub-lethal effects of herbicide may be sufficient to set back the weed so that the crop has a clear advantage. In Europe, a number of reports show that weed suppression at reduced herbicide doses can be influenced by crop species (Salonen 1992; Christensen 1994), variety (Richards and Davies 1991; Christensen 1994), and seeding rate (Barton et al. 1992; Salonen 1992). In Australia, improved wheat CA in densely sown crops was maintained even when treated with reduced rates of herbicides (Walker et al. 1998). When sprayed with the same herbicide rate, seed production of Avena spp. and P. paradoxa was consistently much less as wheat density increased from 50 to 150 plants $/ \mathrm{m}^{2}$. Lemerle et al. (1996b) also showed that reliability of herbicide performance for controlling $L$. rigidum was greatest with strongly competitive wheat varieties. They found that diclofopmethyl at $0.28 \mathrm{~kg} /$ ha reduced L. rigidum biomass to $<100 \mathrm{~g} /$ $\mathrm{m}^{2}$ with the strongly competitive variety Katunga, compared with $200 \mathrm{~g} / \mathrm{m}^{2}$ with the other poorly competitive varieties Rosella and Shrike.

Interactions between agronomic factors and wheat $\mathrm{CA}$ are well documented and can be relatively simple, low-cost options for enhancing wheat competitiveness. More attention needs to be given to demonstrating to farmers the potential benefits of agronomic methods of improving CA of wheat, and once farmers realise the benefits, adoption of this technology could be rapid. A number of researchers in Australia are currently working with farmer groups to undertake on-farm evaluation of crop seeding rate and choice of variety to enhance crop vigour and CA, and it appears that farmer adoption is high, particularly on farms affected by herbicide-resistant weeds (S. J. M. Sutherland, pers. comm.).

\section{Benefits and costs of enhanced competitiveness in wheat}

We have shown in this review that there is considerable evidence supporting the potential to improve the competitiveness of wheat both by genetic gains and also by manipulating the crop environment to favour the crop rather than the weed. However, the success and adoption of this technique will ultimately depend on the benefits relative to the costs. The benefits of strongly competitive wheat are: $(a)$ reduced need for post-emergence herbicides, $(b)$ less selection pressure for herbicide resistance, $(c)$ less herbicide in the environment, $(d)$ reduced risk of herbicides contaminating food, (e) more reliable performance of herbicides in adverse environmental conditions, $(f)$ less emphasis on cultivation for weed management and the associated risk of soil erosion, and $(g)$ reduced weed densities in future weed populations. Some of these benefits are intangible and therefore difficult to measure, and may benefit the whole community as well as farmers (e.g. less herbicides in the environment). Others, such as reduced need for a post-emergence spray provide a very obvious immediate cost saving for farmers. The costs of competitive cropping are: (a) additional seed and sowing costs, (b) research needed to breed a new competitive variety, and (c) the identification and removal of any penalties associated with high competitiveness in wheat (e.g. loss in wheat grain yield or quality, disease susceptibility).

The time-frames of the various benefits and costs vary considerably and need to be considered in the analysis, as does the potential rate of adoption of the technology. For example, manipulation of crop agronomy is a short-term approach compared with breeding, which is much longer term.

Two types of economic analysis are required to evaluate the benefits and costs of greater competitiveness in wheat. Firstly, an analysis is needed to justify the allocation of resources by research agencies to continue to undertake the research required to develop the technology. This must take into account the benefits at both the farmer and wider community levels. Secondly, when the technology becomes available to farmers, the economics of the technology in both the short and long-term will dictate adoption by growers. Bio-economic models are available to help farmers make cost-effective weed management decisions by evaluating the economics of alternative strategies (e.g. Jasieniuk et al. 1999; Jones and Medd 2000). Such models must take into account the inherent environmental variability of weed-crop competition interactions, and a long-time framework for managing weed populations.

\section{Conclusions}

Considerable potential exists to improve the competitiveness of wheat by breeding or agronomy but the benefits and cost of crop CA need to be evaluated. Weeds readily adapt to changes in their environment (Barrett 1983); for example, if 
a new wheat variety with faster canopy cover became the most widely grown type, it is likely that weed ecotypes would evolve that tolerate shading and have a faster rate of height gain. Therefore, wheat competitiveness must be considered as only one part of an overall integrated weed control strategy comprising many different tactics.

Crop CA will become more important as herbicideresistant weeds become more widespread and farmers have fewer herbicide options for weed management. Assuming that research is continued to develop the technology, it is likely that in the long-term, new varieties of wheat will be developed that have features which enhance their competitiveness. The time it will take to achieve this is difficult to predict. In the shortterm, it is likely that manipulating crop agronomy by choice of variety, planting date, seeding rate, and fertiliser (type, timing, rate, and placement) will increase the competitiveness of wheat with weeds.

The need for further experimentation to accurately estimate the relative ranking of current wheat varieties for $\mathrm{CA}$, at the regional level, is debatable. The evidence so far suggests that a few varieties are consistently more competitive than others, but considerable environmental variation exists, making reliable recommendations for farmers difficult. Advising farmers to grow vigorous crops by as many means as possible (e.g. variety, seeding rate, fertiliser, high quality seed, sowing date) is desirable. Changing farming practices, such as the move from conventional cultivation to reduced tillage and stubble retention systems, may influence weed growth and population dynamics (e.g. Cardina et al. 1998) and also wheat vigor and variety $\mathrm{CA}$. This area requires further study. The impact of climate change on wheat CA may also need to be considered. More research is needed to determine the impact of variety CA on weed seed production for population dynamics modelling, particularly with weed species other than $L$. rigidum, to assist in predicting the long-term benefits of integrated weed management. More studies are required to determine variety $\mathrm{CA}$ in other crops, particularly the poorly competitive pulses. Future weed-crop studies of CA must consider both crop tolerance of competition and interference effects of varieties, so that all the benefits of increasing CA of varieties are identified.

The practicality of screening for CA in the later stages of crossbred evaluation in a breeding program (using direct or indirect screening) will depend on having sufficient seed available, having a wide enough range of genetic diversity, the cost of evaluation, and the importance the wheat breeder attributes to CA compared with other selection criteria. Generally, selection for yield potential, disease resistance, and wheat quality will be considered more important than CA. Such screening must be done at the regional level, and any penalties associated with $\mathrm{CA}$ must be identified. Breeding specifically for CA, or for traits known to be associated with $\mathrm{CA}$, is a longer term solution and depends on importing new traits and incorporating these into locally adapted lines. Considerable progress has been made in identifying wheat plant traits associated with $\mathrm{CA}$, and the apparent high heritability of some of these, such as leaf area (leaf length and width), early vigour, and allelopathy, suggests considerable opportunity to breed for CA, either by standard breeding, and/or by biotechnology in the future. The genetic control or heritability of these traits, and the genetic correlation between the traits and $\mathrm{CA}$, will determine the rate of progress in breeding. Breeding for early vigour is already in progress. The increasing importance of herbicideresistant weeds may force breeders to consider breeding for $\mathrm{CA}$ as a higher priority than it currently is, and demand greater resource allocation in this area.

Manipulation of crop agronomy, such as increasing seeding rate, will be useful for making wheat more competitive. More research is needed on the benefits of strategic use of fertiliser to favour the crop rather than the weed, and the interactions with other management tactics such as herbicides. The benefits of reductions in herbicide doses with optimal agronomy to enhance competitiveness of wheat have important implications for managing herbicideresistant weeds.

The complex interaction of climatic and edaphic factors, resource availability, and morphological, phenological, physiological, and biochemical characteristics of the crop and weed make the outcome of competition highly variable and therefore difficult to predict. The use of bio-economic models, based on inputs from competition simulation modelling and simple population dynamic models, will provide information to help growers use competitive wheat cost-effectively. This will also facilitate the allocation of the research and development resources required to develop this technology, and accelerate the adoption of competitive varieties by farmers.

\section{Acknowledgments}

We thank Anthony Van Herwaarden and the referees for constructive criticism of an earlier version of the manuscript.

\section{References}

Allard RW (1960) 'Principles of plant breeding.' (John Wiley: New York)

Anderson RL (1991) Timing of nitrogen application affects downy brome (Bromus tectorum) growth in winter wheat. Weed Technology 5, 582-585.

Angonin C, Caussanel JP, Meynard JM (1996) Competition between winter wheat and Veronica hederifolia: influence of weed density and the amount and timing of nitrogen application. Weed Research 36, $175-187$.

Appleby AP, Olson PD, Colbert DR (1976) Winter wheat yield reduction from interference by Italian ryegrass. Agronomy Journal 68, 463-466.

Baghestani A, Lemieux C, Leroux GD, Baziramakenga R, Simard RR (1999) Determination of allelochemicals in spring cereals of different competitiveness. Weed Science 47, 498-504. 
Balyan RS, Malik RK, Panwar RS, Singh S (1991) Competitive ability of winter wheat cultivars with wild oat (Avena ludoviciana). Weed Science 39, 154-158.

Barrett SCH (1983) Crop mimicry in weeds. Economic Botany 37, 255-282.

Barrett DW, Campbell NA (1973) An evaluation of effects of competition between wheat and Wimmera ryegrass (Lolium rigidum) during early stages of growth. Australian Journal of Experimental Agriculture and Animal Husbandry 13, 581-586.

Barton DL, Thill DC, Shafii B (1992) Integrated wild oat (Avena fatua) management affects spring barley (Hordeum vulgare) yield and economics. Weed Technology 6, 129-135.

Bastiaans L, Kropff MJ, Kempuchetty N, Rajan A, Migo TR (1997) Can simulation models help design rice cultivars that are more competitive against weeds? Field Crops Research 51, 101-111.

Bingham IJ (1995) A comparison of the dynamics of root growth and biomass partitioning in wild oat (Avena fatua $\mathrm{L}$.) and spring wheat. Weed Research 35, 57-66.

Blackshaw RE (1994) Differential competitive ability of winter wheat cultivars against downy brome. Agronomy Journal 86, 649-654.

Blackshaw RE, Stobbe EH, Sturko ARW (1981) Effect of seeding dates and densities of green foxtail (Setaria viridis) on the growth and productivity of spring wheat (Triticum aestivum). Weed Science 29, 212-217.

Borrell AK, Incoll LD, Dalling MJ (1993) The influence of Rht 1 and $R h t 2$ alleles on the deposition and use of stem resources in wheat. Annals of Botany 71, 317-326.

Callaway MB, Forcella F (1993) Crop tolerance to weeds. In 'Crop improvement for sustainable agriculture systems'. (Eds MB Callaway, CA Francis) pp. 100-131. (University of Nebraska Press: Lincoln, NE)

Cardina J, Webster TM, Herms CP (1998) Long-term tillage and rotation effects on soil seedbank characteristics. Aspects of Applied Biology 51, 213-220.

Carlson HL, Hill JE (1986) Wild oat (Avena fatua) competition with spring wheat: Effects of nitrogen fertilisation. Weed Science 34, 29-33.

Challaiah O, Ramsel RE, Wicks GA, Burnside OC, Johnson VA (1983) Evaluation of the weed competitive ability of winter wheat cultivars. Proceedings of the North Central Weed Control Conference 38, 85-91.

Challaiah O, Burnside OC, Wicks GA, Johnson VA (1986) Competition between winter wheat (Triticum aestivum) cultivars and downy brome (Bromus tectorum). Weed Science 34, 689-693.

Christensen S (1994) Crop weed competition and herbicide performance. Weed Research 34, 29-36.

Cochran VL, Morrow LA, Shirman RD (1990) The effect of N placement on grass weeds and winter wheat responses in three tillage systems. Soil Tillage Research 18, 347-355.

Cosser ND, Gooding MJ, Froud-Williams RJ (1995) The effect of wheat dwarfing genes on competition against blackgrass. In 'Proceedings of the Brighton Crop Protection ConferenceWeeds'. pp. 361-362. (British Crop Protection Council: Farnham, UK)

Cosser ND, Gooding MJ, Davies WP, Thompson AJ (1997) Cultivar and $R h t$ gene influences on the competitive ability, yield and the bread-making quality of organically grown winter wheat. Aspects of Applied Biology 50, 39-51.

Cousens RD, Fletcher DJ (1990) Experimental design for screening for competitiveness of crop cultivars. In 'Proceedings of the 9th Australian Weeds Conference’. pp. 163-165. (Ed. JW Heap) (Crop Science Society of South Australia: Adelaide)

Cousens RD (1991) Aspects of the design and interpretation of competition (interference) experiments. Weed Technology 5, 664-673.
Cousens RD (1996) Comparative growth of wheat, barley, and annual ryegrass (Lolium rigidum) in monoculture and mixture. Australian Journal of Agricultural Research 47, 449-464.

Cousens RD, Mokhtari S (1998) Seasonal and site variability in the tolerance of wheat cultivars to interference from Lolium rigidum. Weed Research 38, 301-307.

Da Silva AR (1976) Application of genetic approach to wheat culture in Brazil. In ' Plant Adaptation to Mineral Stress in Problem Soils'. Proceedings of a Workshop, Beltsville, 1976. (Eds MJ Wright, AS Ferrari) pp. 223-231. (Cornell University Press: Ithaca, NY)

De Lucas CB, Froud-Williams RJ (1994) The role of varietal selection for enhanced crop competitiveness in winter wheat. Aspects of Applied Biology 40, 343-350.

Dilday RH, Yan WG, Moldenhauer KAK, Gravois KA (1998) Allelopathic activity in rice for controlling major aquatic weeds. In 'Allelopathy in Rice'. (Ed. M Olofsdotter) pp. 7-26. (IRRI: Los Baños, Philippines)

Di Tomaso JM (1995) Approaches for improving crop competitiveness through manipulation of fertiliser strategies. Weed Science 43, 491-497.

Doll H, Holm U, Sogaard B (1995) Effect of crop density on competition by wheat and barley with Argostemma githago and other weeds. Weed Research 35, 391-396.

Donald CM, Hamblin J (1976) The biological yield and harvest index of cereals as agronomic and plant breeding criteria. Advances in Agronomy 28, 361-402.

Dotray PA, Young FL (1993) Characterisation of root and shoot development of goated goatgrass (Aegilops cylindria). Weed Science 41, 353-361.

Downing RG (1921) Thick or thin seeding for wheat? Agricultural Gazette of N.S.W. p. 205

Eberhart SA, Penny LA, Sprague GF (1964) Intraplot competition among maize single crosses. Crop Science 4, 467-471.

Evans RM, Thill DC, Tapia L, Shafii B, Lish JM (1991) Wild oat (Avena fatua) and spring barley (Hordeum vulgare) density affect spring barley yield. Weed Technology 5, 33-39.

Fischer RA, Miles RE (1973) The role of spatial pattern in the competition between crop plants and weeds: A theoretical analysis. Mathematical Biosciences 18, 335-350.

Fischer RA, Quail KJ (1990) The effect of major dwarfing genes on yield potential in spring wheats. Euphytica 46, 51-56.

Fleming GF, Young FL, Ogg AG Jr (1988) Competitive relationships among winter wheat (Triticum aestivum), jointed goatgrass (Aegilops cylindrica), and downy brome (Bromus tectorum). Weed Science 36, 479-486.

Flintham JE, Borner A, Worland AJ, Gale MD (1997) Optimising wheat grain yield: effects of $R h t$ (gibberellin-insensitive) dwarfing genes. Journal of Agricultural Science 128, 11-25.

Fofana B, Koupeur T, Jones MP, Johnson DE (1995) The development of rice varieties competitive with weeds. In 'Proceedings of the Brighton Crop Protection Conference-Weeds'. pp. 187-192. (British Crop Protection Council: Farnham, UK)

Forcella F (1984) Wheat and ryegrass competition for pulses of mineral nitrogen. Australian Journal of Experimental Agriculture and Animal Husbandry 24, 421-425.

Forcella F (1987) Tolerance of weed competition associated with high leaf-area expansion rate in tall fescue. Crop Science 27, 146-147.

Gates CT, Jones DB, Muller WJ, Hicks JS (1981) The interaction of nutrients and tillage methods on wheat and weed development. Australian Journal of Agricultural Research 32, 227-241.

Gill GS (1996a) Why is annual ryegrass a problem in Australian Agriculture. Plant Protection Quarterly 11, 193-194.

Gill GS (1996b) Ecology of annual ryegrass. Plant Protection Quarterly 11, 195-198. 
Gill GS, Holmes JE (1997) Efficacy of cultural control methods for combating herbicide-resistant Lolium rigidum. Pesticide Science 51, 352-358.

Gill GS, Coleman R (1999) The use of a double haploid population to investigate the relationship between crop morphological traits and competitiveness with weeds. In 'Proceedings of the 12th Australian Weeds Conference'. (Eds AC Bishop, M Boersma, CD Barnes) pp. 501-505. (Tasmanian Weed Society: Hobart)

Gill G, Colemen R (2000) Have gains in yielding ability compromised weed competitiveness of modern wheat cultivars. In 'Proceedings of the 3rd International Weed Control Congress'. Abstr. (Ed. A Lêgere) p. 59. (International Weed Science Society: Corvallis, Oregon)

Goldberg DE (1990) Components of resource allocation in plant communities. In 'Perspectives in plant competition' (Eds JB Grace, D Tilman) pp. 27-49. (Academic Press: San Diego)

GRDC (1998) Research Update-Competitive crops. Grains Research and Development Corporation, Canberra, ACT.

Grundy AC, Froud-Williams RJ (1993) The use of cultivar, crop seed rate and nitrogen level for the suppression of weeds in winter wheat. In 'Proceedings of the Brighton Crop Protection ConferenceWeeds'. pp. 997-1001. (British Crop Protection Council: Farnham, UK)

Harlan HV, Martini ML (1938) The effect of natural selection in a mixture of barley varieties. Agricultural Research 57, 189-199.

Harper JL (1977) 'Population biology of plants.' (Academic Press: New York)

Hashem A, Adkins SW (1996) Introduction of allelopathy to wheat: effect of Triticum speltoides on two weeds of wheat. In 'Proceedings of the 11th Australian Weeds Conference'. (Ed. RCH Shepherd) pp. 45-48. (Weed Science Society of Victoria: Melbourne)

Hashem A, Radosevich SR, Roush ML (1998) Effect of proximity factors on competition between winter wheat (Triticum aestivum) and Italian ryegrass (Lolium multiflorum). Weed Science 46, 181190 .

Heap IM, Knight R (1982) A population of ryegrass tolerant to the herbicide diclofop-methyl. Journal of Australian Institute Agricultural Sciences 48, 156-157.

Heneise HK, Murray GA (1980) Effect of row spacing on yield of spring planted Australian winter field pea. Agronomy Journal 72, 369-371.

Hoen K, Oram RN (1967) Establishment of perennial pasture grasses under a cover crop in a Mediterranean-type environment. Australian Journal of Experimental Agriculture and Animal Husbandry 7, 241-248.

Huel DG, Hucl P (1996) Genotypic variation for competitive ability in spring wheat. Plant Breeding 115, 325-329.

Iqbal J, Wright D (1997) Effects of nitrogen supply on competition between wheat and three annual weed species. Weed Research 37, 391-400.

Jasieniuk M, Maxwell BD, Anderson RL, Evans JO, Lyon DJ, Miller SD, Morishita DW, Ogg AG Jr, Seefeldt S, Stahlman PW, Northam FE, Westra P, Kebede Z, Wicks GA (1999) Site-to-site and year-toyear variation in Triticum aestivum-Aegilops cylindrica interference relationships. Weed Science 47, 529-537.

Jennings PR, Aquino RC (1967) Studies on competition in rice. III. The mechanism of competition among phenotypes. Evolution 22, $529-542$.

Jensen NF, Federer WT (1965) Competing ability in wheat. Crop Science 5, 449-452.

Jones RE, Medd RW (2000) Economic thresholds and the case for longer term approaches to population management of weeds. Weed Technology 14, 337-350.
Jordan N (1993) Prospects for weed control through weed suppression. Ecological Applications 3, 84-91.

Jørnsgård B, Rasmussen K, Hill J, Christiansen JL (1996) Influence of nitrogen on competition between cereals and their natural populations. Weed Research 36, 461-470.

Kirkland KJ (1993) Weed management in spring barley (Hordeum vulgare) in the absence of herbicides. Journal of Sustainable Agriculture 3, 95-104.

Kirkland KJ, Beckie HJ (1998) Contribution of nitrogen fertiliser placement to weed management in spring wheat (Triticum aestivum). Weed Technology 12, 507-514.

Korres NE, Froud-Williams RJ (1997) The use of varietal selection and seed rates for enhanced weed suppression in winter wheat (Triticum aestivum L.). In 'Proceedings of the Brighton Crop Protection Conference-Weeds'. pp. 667-668. (British Crop Protection Council: Farnham)

Laing DR, Fischer RA (1977) Adaptation of semi-dwarf cultivars to rain-fed conditions. Euphytica 26, 129-139.

Lêgere A, Samson N, Rioux R, Angers DA, Simard RR (1997) Response of spring barley to crop rotation, conservation tillage and weed management intensity. Agronomy Journal 89, 628-638.

Lemerle D, Michael PW, Sutton BG (1979) The competitive abilities of wheat and triticale against different densities of Lolium rigidum. In 'Proceedings of the 7th Asian-Pacific Weed Science Society Conference'. (Eds RW Medd, BA Auld) pp. 447-450. (AsianPacific Weed Science Society: Melbourne)

Lemerle D, Verbeek B, Coombes N (1995) Losses in grain yield of winter crops from Lolium rigidum competition depend on cultivar and season. Weed Research 35, 503-509.

Lemerle D, Verbeek B, Cousens RD, Coombes NE (1996a) The potential for selecting wheat varieties strongly competitive against weeds. Weed Research 36, 505-513.

Lemerle D, Verbeek B, Coombes NE (1996b) Interaction between wheat (Triticum aestivum) and diclofop to reduce the cost of annual ryegrass (Lolium rigidum) control. Weed Science 44, 634-639.

Lemerle D, Martin P, Smith A, Verbeek B, Rudd S (2000) Breeding for competitive cultivars of wheat. In 'Proceedings of the 3rd International Weed Control Congress'. Abstr. (Ed. A Lêgere) p. 75. (International Weed Science Society: Corvallis, OR)

Lemerle D, Verbeck B, Orchard B (2001) Ranking the ability of wheat varieties to compete with Lolium rigidum. Weed Research 41 (in press).

Liang YL, Richards RA (1994) Coleoptile tiller development is associated with fast early vigour in wheat. Euphytica 80, 119-124.

Lintell-Smith G, Baylis J M, Watkinson AR, Firbank LG (1992) The effects of reduced nitrogen and weed competition on the yield of winter wheat. Aspects of Applied Biology 30, 367-372.

López-Castañeda C, Richards RA, Farquhar GD, Williamson RE (1996) Seed and seedling characteristics contributing to variation in early vigour among temperate cereals. Crop Science 36, 1257-1266.

Lotz LAP, Groeneveld RMW, de Groot NAMA (1991) Potential for reducing herbicide inputs in sugar beet by selecting early closing cultivars. In 'Proceedings of the Brighton Crop Protection Conference-Weeds'. pp. 1241-1248. (British Crop Protection Council: Farnham, UK)

Luckett DJ, Edwards KJR (1986) Esterase genes in parallel composite cross barley populations. Genetics 114, 289-302.

Luckett DJ, Sharif AL (1987) Metrical characters in parallel-grown sub-populations of barley Composite Cross Five. Australian Journal of Biological Sciences 40, 65-77.

Lutman PJW, Dixon FL, Risiott R. (1994) The response of four springsown combinable arable crops to weed competition. Weed Research 34, 137-146. 
Martin RJ, Cullis BR, McNamara DW (1987) Prediction of wheat yield loss due to competition by wild oats (Avena spp.). Australian Journal of Agricultural Research 38, 487-499.

Medd RW, Auld BA, Kemp DR, Murison RD (1985) The influence of wheat density on spatial arrangement on annual ryegrass, Lolium rididum Gaudin, competition. Australian Journal of Agricultural Research 36, 361-371.

Melander B (1993) Modelling the effects of Elysmus repens (L.) Gould competition on yield of cereals, peas and oilseed rape. Weed Research 33, 99-108.

Millington S, Stopes C, Woodward L, Voghtmann H (1990) Rotational design and the limits of organic systems - the stockless organic farm. In 'Organic and low input agriculture'. pp. 163-173. British Crop Protection Council Monograph No. 45.

Mokhtari S (1998) Environmental and genetic aspects of the ability of wheat cultivars to compete with annual ryegrass (Lolium rigidum). $\mathrm{PhD}$ thesis, The University of Western Australia.

Moss SR (1985) The influence of crop variety and seed rate on Alopecurus myosuroides competition in winter cereals. In 'Proceedings of the Brighton Crop Protection ConferenceWeeds'. pp. 701-708. (British Crop Protection Council: Farnham, UK)

Murphy C (1998) An eco-physiological analysis of competition for water between cereals and annual ryegrass (Lolium rigidum). $\mathrm{PhD}$ thesis, The University of Sydney.

Nalewaja JD (1978) Weed control in cereals - now and in the future. In 'Proceedings of the First Conference of the Council of Australian Weed Science Societies'. (Eds WT Parsons, FC Eady, RG Richardson) pp. 215-222. (Council of Australian Weed Science Societies: Melbourne)

Ogg AG Jr, Seefeldt SS (1999) Characterising traits that enhance the competitiveness of winter wheat (Triticum aestivum) against jointed goatgrass (Aegilops cylindrica). Weed Science 47, 74-80.

Olofsdotter M, Navarez DC (1996) Allelopathic rice for Echinochloa crus-galli control. In 'Proceedings of the 2nd International Weed Control Congress'. (Eds H Brown, GW Cussans, MD Devine, SO Duke, C Fernadez-Quintanilla, A Helweg, RE Labrada, M Landes, P Kudsk, JC Streibig) pp. 1175-1181. (International Weed Science Society: Flakkebjerg)

Ortiz-Monasterio JI, Sayre KD, Rajaram S, McMahon (1997) Genetic progress in wheat yield and nutrient use efficiency under four nitrogen rates. Crop Science 37, 898-904.

Pageau D, Tremblay GF (1995). Effect of quackgrass on the productivity of barley seeded at different seeding rates and row spacings. Canadian Journal of Plant Science 75, 613-618.

Paseban-Islam B, Shakiba MR, Moghaddam-Vahed M, Jozan J (1999) Storage and remobilization of non-structural carbohydrates of stem in spring wheat isolines under drought/water deficit stress. Iranian Journal of Agricultural Sciences 29, 733-742.

Pavlychenko TK, Harrington JB (1934) Competitive efficiency of weeds and cereal crops. Canadian Journal of Research 10, 77-94.

Pavlychenko TK, Harrington JB (1935) Root development of crop weeds and crops under dry farming. Scientific Agriculture 16, 151-159.

Peltzer S (1999) Increased crop density reduces weed seed production without increasing screenings. In 'Proceedings of the 12th Australian Weeds Conference'. (Eds AC Bishop, M Boersma, CD Barnes) pp. 510-512. (Tasmanian Weed Society: Hobart)

Penning de Vries FWT (1991) Improving yield: Designing and testing VHYVs. In 'Systems simulation at IRRI'. IRRI Research Paper Series 151. pp. 13-17. (International Rice Research Institute: Manilla)

Pester TA, Burnside OC, Orf JH (1999) Increasing crop competitiveness to weeds through crop breeding. Journal of Crop Production 2, 59-76.
Ponce RG (1998) Competition between barley and Lolium rigidum for nitrate. Weed Research 38, 453-460.

Powles SB, Preston C, Bryan IB, Jutsum AR (1997) Herbicide resistance: impact and management. Advances in Agronomy 58, 57-93.

Preston C, Roush RT, Powles SB (1999) Herbicide resistance in weeds of southern Australia: why are we the worst in the world? In 'Proceedings of the 12th Australian Weeds Conference'. (Eds AC Bishop, M Boersma, CD Barnes) pp. 454-459. (Tasmanian Weed Society: Hobart)

Putnam DH, Wright J, Field LA, Ayisi KK (1992) Seed yield and wateruse efficiency of white lupin as influenced by irrigation, row spacing and weeds. Agronomy Journal 84, 557-563.

Radford BJ, Wilson BJ, Cartledge O, Watkins FB (1980) Effect of wheat seeding rate on wild oat competition. Australian Journal of Experimental Agriculture and Animal Husbandry 20, 77-81.

Rasmussen PE (1995) Effects of fertiliser and stubble burning on downy brome competition in winter wheat. Communications in Soil Science and Plant Analysis 26, 951-960.

Rebetzke GJ, Richards RA (1996) Improving the establishment and early vigour of wheat. In 'Proceedings of the 8th Australian Agronomy Conference'. (Ed. M Asghar) pp. 466-469. (The Australian Society of Agronomy: Toowoomba, Qld)

Rebetzke GJ, Richards RA (1999) Genetic improvement of early vigour in wheat. Australian Journal of Agricultural Research 50, 291-301.

Rebetzke GJ, Richards RA, Fischer VM, Mickelson BJ (1999) Breeding long coleoptile, reduced height wheats. Euphytica 106, 159-168.

Reeves TG (1976) Effect of annual ryegrass (Lolium rigidum Gaud.) on yield of wheat. Weed Research 16, 57-63.

Reeves TG, Brooke HD (1977) The effect of genotype and phenotype on the competition between wheat and annual ryegrass (Lolium rigidum Gaud.). In 'Proceedings of the 6th Asian-Pacific Weed Science Society Conference'. (Eds M Soerjani, DE Barnes, TO Robson) pp. 167-172. (Asian-Pacific Weed Science Society: Jakarta)

Reeves TG, Nietschke BS, Hollamby GJ, Powles SB (1993) Integrated weed management - the role of competitive cultivars. In 'Proceedings of the 7th Australian Agronomy Conference'. (Eds GK McDonald, WD Bellotti) p. 409. (Australian Agronomy Society: Adelaide)

Remison SU, Snaydon RW (1978) Yield, seasonal changes in root competitive ability and competition for nutrients among grass species. Journal of Agricultural Science 90, 115-124.

Reynolds MP, Acevedo E, Sayre KD, Fischer RA (1994) Yield potential in modern wheat varieties: its association with a less competitive ideotype. Field Crops Research 37, 149-160.

Rezaul Karim EM, Naylor REL, Whytock GP (1997) Aggressivity of wheat cultivars. In 'Proceedings of the Brighton Crop Protection Conference-Weeds'. pp. 665-666. (British Crop Protection Council: Farnham, UK)

Rice EL (1995) Biological control of weeds and plant disease: In 'Advances in applied allelopathy'. (University of Oklahoma Press: Norman, OK)

Richards MC (1989) Crop competitiveness as an aid to weed control. In 'Proceedings of the Brighton Crop Protection ConferenceWeeds'. pp. 573-578. (British Crop Protection Council: Farnham, UK)

Richards RA (1992) The effect of dwarfing genes in spring wheat in dry environments. 1. Agronomic characteristics. Australian Journal of Agricultural Research 43, 517-527.

Richards MC (1993) The effects of agronomic factors on competition between cereals and weeds; the implications in integrated crop production. In 'Proceedings of the Brighton Crop Protection Conference-Weeds'. pp. 991-996. (British Crop Protection Council: Farnham, UK) 
Richards MC, Davies DH K (1991) Potential for reducing herbicide inputs/rates with more competitive cereal cultivars. In 'Proceedings of the Brighton Crop Protection Conference-Weeds’. pp. 12331240. (British Crop Protection Council: Farnham, UK)

Richards MC, Whytock GP (1993) Varietal competitiveness with weeds. Aspects of Applied Biology 34, 345-354.

Salonen J (1992) Efficacy of reduced herbicide doses in spring cereals of different competitive ability. Weed Research 32, 483-491.

Seavers GP, Wright KJ (1999) Crop canopy development and structure influence weed suppression. Weed Research 39, 319-328.

Seefeldt S, Ogg GO, Hou Y (1999) Near-isogenic lines for Triticum aestivum height and crop competitiveness. Weed Science 47, 316320

Smith DF, Levick GRT (1974) The effect of infestation by Lolium rigidum Gaud. (annual ryegrass) on the yield of wheat. Australian Journal Agricultural Research 25, 381-393.

Sturko ARW, Stobbe, EH (1976) Green foxtail competition in semidwarf and normal height spring wheat. In 'Proceedings of the North Central Weed Control Conference 31'. p. 40.

Suneson CA, Wiebe GA (1942) Survival of barley and wheat varieties in mixtures. American Society of Agronomy 34, 1052-1056.

Thill D, Lemerle D (2001) Resistance management in wheatdominated agro-ecosystems. In 'Herbicide resistance management in world grain crops'. (Eds D Shaner, SB Powles) pp. 165-194. (CRC Press: Boca Raton, FL) (in press)

Thurston JM (1959) A comparative study of the growth of wild oats (Avena fatua L. and A. ludoviciana Dur.) and of cultivated cereals with varied nitrogen supply. Annals of Applied Biology 47, 716739

Valenti SA, Wicks GA (1992) Influence of nitrogen rates and wheat (Triticum aestivum) cultivars on weed control. Weed Science 40, 115-121.

Van Heemst HD (1985) The influence of weed competition on crop yield. Agricultural Systems 18, 81-93.

Verschwele A (1994) Cultivar-specific competition in winter wheat with weed growth as a limiting factor. PhD thesis, The University of Göttingen.
Verschwele A, Niemann P (1993) Indirekte unkrautbekampfung durch sortenwahl bei weizen. In 'Proceedings of the 8th European Weed Research Society Symposium'. (Compiled by T Eggers) pp. 709806. (European Weed Research Society: Braunschweig)

Walker SR, Robinson GR, Medd RW (1998) Management of wild oats and paradoxa grass with reduced dependence on herbicides. In 'Proceedings of the 9th Australian Agronomy Conference'. (Eds DL Michalk, JA Pratley) pp. 572-574. (Australian Society of Agronomy: Wagga Wagga, NSW)

Wicks GA, Ramsel RE, Nordquist PT, Schmidt JW, Challaiah O (1986) Impact of wheat cultivars on establishment and suppression of summer annual weeds. Agronomy Journal 78, 59-62.

Woodruff DR, Tonks J (1983) Relationship between time of anthesis and grain yield of wheat genotypes with differing developmental patterns. Australian Journal of Agricultural Research 34, 1-11.

Wu H, Pratley JE, Lemerle D, Haig T, Verbeek B (1998) Differential allelopathic potential among wheat accessions to annual ryegrass. In 'Proceedings 9th Agronomy Conference'. (Eds DL Michalk, JE Pratley) pp. 567-571. (Australian Society of Agronomy: Wagga Wagga, NSW)

Wu H, Pratley JE, Lemerle D, Haig T (1999a) Crop cultivars with allelopathic capability. Weed Research 39, 171-180.

Wu H, Haig T, Pratley JE, Lemerle D, Min A (1999b) Simultaneous determination of phenolic acids and 2,4-dihydroxy-7-methoxy-1,4benzoxazin-3-one in wheat (Triticum aestivum) by gas chromatography-tandem mass spectrometry. Journal of Chromatography. A 864, 315-321.

Wu H, Pratley JE, Lemerle D, Haig T (2001) Evaluation of seedling allelopathy in 453 wheat (Triticum aestivum) accessions against annual ryegrass (Lolium rigidum) by Equal-compartment-AgarMethod. Australian Journal of Agricultural Research 51, 937-944.

Young FL, Seefeldt SS, Barnes GF (1999) Planting geometry of winter wheat (Triticum aestivum) can reduce jointed goatgrass (Aegilops cylindrica) spikelet production. Weed Technology 13, 183-190.

Manuscript received 29 March 2000, accepted 11 December 2000 